\title{
Integrated Status and Effectiveness Monitoring Program - Entiat River Rotary Screw Traps, Snorkel Surveys, and Steelhead Redd Surveys, 2008.
}

February 2008- January 2009

\author{
Prepared by: \\ Tom Desgroseillier \\ Michael Cotter \\ Matt Cooper \\ R.D. Nelle \\ Drew Pearson \\ Andy Johnsen \\ U.S. Fish and Wildlife Service \\ Mid-Columbia River Fishery Resource Office \\ 7501 Icicle Rd. \\ Leavenworth WA 98826 \\ Funded by \\ U.S. Department of Energy \\ Bonneville Power Administration \\ Division of Fish and Wildlife \\ Portland, OR. 97208-3621
}

Project No. 2003-017-00

Contract No. 28029

January, 2009 


\begin{abstract}
The USFWS Mid-Columbia River Fishery Resource Office (MCRFRO) operated two rotary screw traps on the Entiat River as part of the Integrated Status and Effectiveness Monitoring Program program from March through November of 2008. Along with the smolt traps, juvenile emigrants were also captured at remote locations throughout the Entiat watershed and its major tributary, the Mad River. A total of 16,782 wild salmonids were PIT tagged during the study period. Of this, 3,961(23.6\%) were wild Oncorhynchus mykiss, 6,987 (41.6\%) were wild spring run O. tshawytscha, and 5,591 (33.3\%) were identified as wild $O$. tshawytscha of unknown run. Rotary screw trap efficiencies averaged $40.3 \%$ at the upper (Rkm 11.0) trap and 7.8\% for the lower (Rkm 2.0) trap. These efficiencies were pooled for emigrant $O$. tshawytscha and $O$. mykiss. The MCRFRO conducted effectiveness monitoring snorkel surveys at 24 sites during the winter period and 30 sites during the summer and fall periods of 2008 as part of the Integrated Status and Effectiveness Monitoring Program in the Entiat River. The 2008 steelhead spawning grounds surveys were conducted weekly in the main Entiat River from rkm 1.1 to 44.2. A total of 222 steelhead redds were identified over the period from February 28 to June 162008 with April being the peak spawning month. Approximately $80 \%$ of the steelhead redds were located downstream of the rkm 26.
\end{abstract}




\section{Table of Contents}

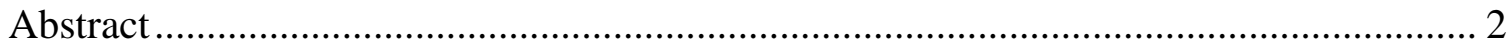

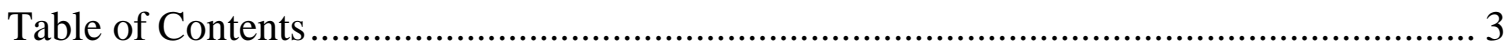

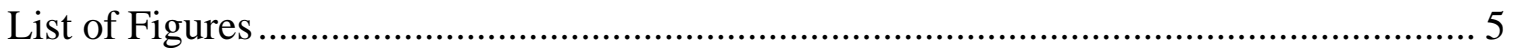

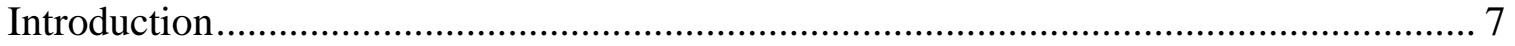

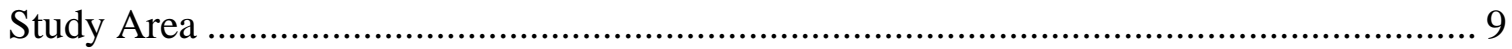

Methods-rotary screw trap ……………………….............................................. 12

Rotary screw trap operation .......................................................................... 12

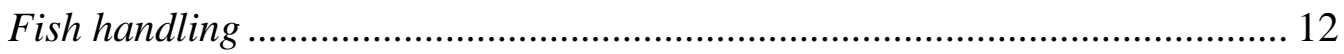

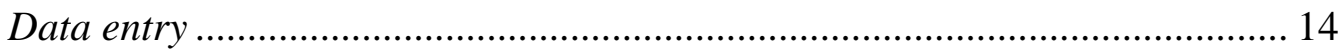

Remote capture for PIT tagging ................................................................... 14

Genetic and scale sampling .......................................................................... 14

Screw trap efficiency ................................................................................... 15

Water temperature and discharge ……………............................................. 15

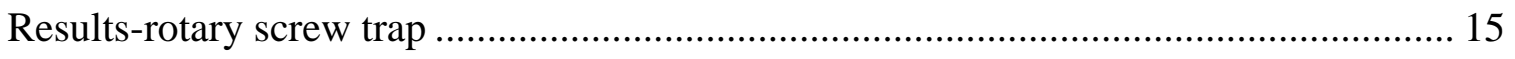

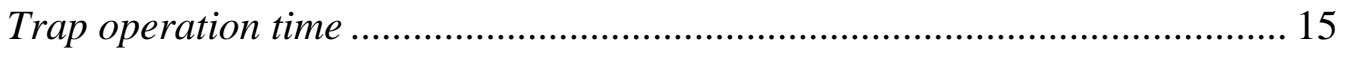

Juvenile emigration........................................................................................ 16

Remote tagging operations ........................................................................... 19

Trap efficiencies......................................................................................... 20

ATM/PTAGIS upload ..................................................................................... 20

Discussion-rotary screw trap................................................................................ 21

Rotary screw trap operation ........................................................................ 21

Summer vs. spring Chinook .......................................................................... 21

Project goals ........................................................................................... 22

Methods- snorkel surveys ……………………………............................................ 22

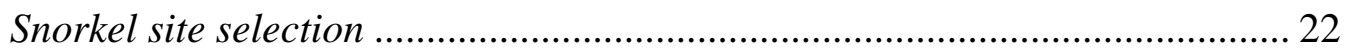

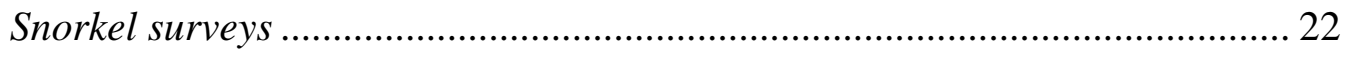

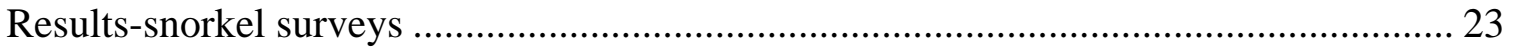




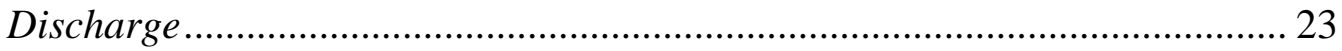

Water temperature ……………………………………………………... 23

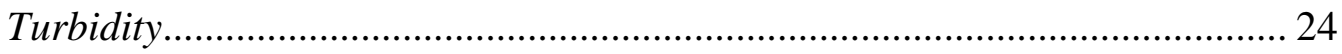

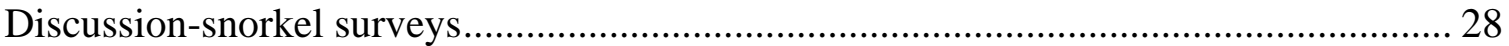

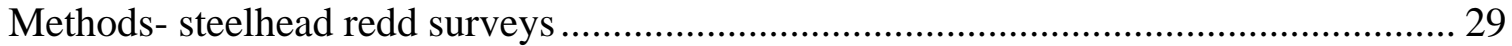

Results-steelhead redd surveys .................................................................................. 29

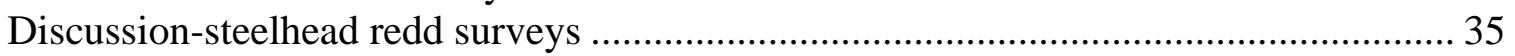

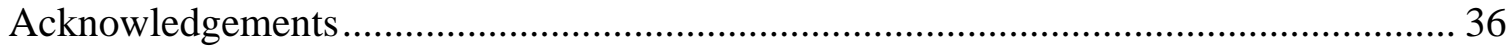

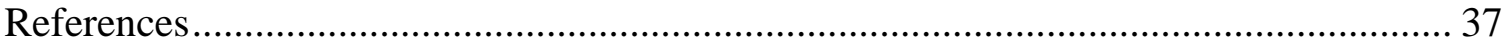




\section{List of Figures}

Figure 1. Study reach map of the Entiat River watershed with the juvenile rotary screw trap locations.

Figure 2. Study reach map of the Entiat River watershed with snorkel survey area from rkm 0.5 to 34.4. Steelhead surveys are located from rkm 1.1 to 44.2 ............. 11

Figure 3. Daily mean discharge $\left(\mathrm{ft}^{3} / \mathrm{sec}\right)$ for the period from February 1 to December 1 , 2008 for USGS gage station 12452990 at rkm 2.3 in the Entiat River.

Figure 4. The cumulative number of number of steelhead redds indentified in the Entiat River from rkm 1.1 to 44.2 during 2008.

Figure 5. Distribution of steelhead redds in the main Entiat River in (rkm 1.1 to 44.2) during 2008.

Figure 6. Distribution of steelhead redds in the Entiat River in Reach A (rkm 1.1 to 10.6) during 2008.

Figure 7. Distribution of steelhead redds in the Entiat River in Reach B (rkm 10.6 to 25.9) during 2008.

Figure 8. Distribution of steelhead redds in the Entiat River in Reach C (rkm 25.9 to 37.7) during 2008.

Figure 9. Distribution of steelhead redds in the Entiat River in Reach D (rkm 37.7 to 44.2) during 2008. 


\section{List of Tables}

Table 1. Rotary screw trap operation from March through November 2008. 15

Table 2. Capture and PIT tag totals of wild juveniles from the lower Entiat River smolt trap (rkm 2) from March through November of 2008.

Table 3. Capture and PIT tag totals of wild juveniles from upper Entiat River smolt trap (rkm 11.0) March through November, 2008.

Table 4. Cumulative capture totals of wild juveniles from both Entiat River smolt traps from March through November, 2008............................................................. 19

Table 5. Upper Entiat River (rkm 11.0) smolt trap efficiency trial results...................... 20

Table 6. Lower Entiat River (rkm 2.0) smolt trap efficiency trial results. ...................... 20

Table 7. Experimental site descriptions and locations snorkeled in the Entiat River during

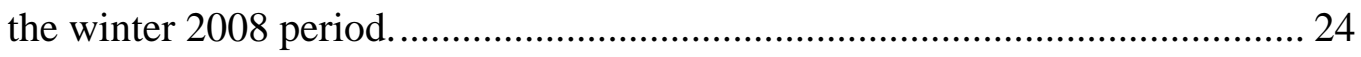

Table 8. Experimental site descriptions and locations snorkeled in the Entiat River during the summer and fall 2008 periods. ............................................................... 25

Table 9. Water quality measurements for sites and times snorkeled in the Entiat River during 2008. Mean discharge data is from USGS gage site number 12452990. 26

Table 10. The number of steelhead redds by reach in the Entiat River from rkm 1.1 to 44.2. during the spring of 2008.

Table 11. The number of steelhead redds indentified in the Entiat River from rkm 1.1 to 44.2 during 2008. 


\section{Introduction}

The Integrated Status and Effectiveness Monitoring Program (ISEMP - BPA project \#2003-0017) has been created as a cost effective means of developing protocols and new technologies, novel indicators, sample designs, analytical, data management and communication tools and skills, and restoration experiments that support the development of a region-wide Research, Monitoring and Evaluation (RME) program to assess the status of anadromous salmonid populations, their tributary habitat and restoration and management actions.

The most straightforward approach to developing a regional-scale monitoring and evaluation program would be to increase standardization among status and trend monitoring programs. However, the diversity of species and their habitat, as well as the overwhelming uncertainty surrounding indicators, metrics, and data interpretation methods, requires the testing of multiple approaches. Thus, the approach ISEMP has adopted is to develop a broad template that may differ in the details among subbasins, but one that will ultimately lead to the formation of a unified RME process for the management of anadromous salmonid populations and habitat across the Columbia River Basin.

ISEMP has been initiated in three pilot subbasins, the Wenatchee/Entiat, John Day, and Salmon. To balance replicating experimental approaches with the goal of developing monitoring and evaluation tools that apply as broadly as possible across the Pacific Northwest, these subbasins were chosen as representative of a wide range of potential challenges and conditions, e.g., differing fish species composition and life histories, ecoregions, institutional settings, and existing data. ISEMP has constructed a framework that builds on current status and trend monitoring infrastructures in these pilot subbasins, but challenges current programs by testing alternative monitoring approaches. In addition, the ISEMP is:

1) Collecting information over a hierarchy of spatial scales, allowing for a greater flexibility of data aggregation for multi-scale recovery planning assessments, and

2) Designing methods that:

a) Identify factors limiting fish production in watersheds;

b) Determine restoration actions to address these problems;

c) Implement actions as a large-scale experiment (e.g. Before After Control Impact, or BACI design), and

d) Implement intensive monitoring and research to evaluate the action's success.

The intent of the ISEMP project is to design monitoring programs that can efficiently collect information to address multiple management objectives over a broad range of scales. This includes:

- Evaluating the status of anadromous salmonids and their habitat; 
- Identifying opportunities to restore habitat function and fish performance, and

- Evaluating the benefits of the actions to the fish populations across the Columbia River Basin.

The multi-scale nature of this goal requires the standardization of protocols and sampling designs that are statistically valid and powerful, properties that are currently inconsistent across the multiple monitoring programs in the region. Other aspects of the program will aid in the ability to extrapolate information beyond the study area, such as research to elucidate causal mechanisms, and a classification of watersheds throughout the Columbia River Basin. Obviously, the scale of the problem is immense and the ISEMP does not claim to be the only program working towards this goal. As such, ISEMP relies heavily on the basin's current monitoring infrastructure to test and develop monitoring strategies, while acting as a coordinating body and providing support for key elements such as data management and technical analyses. The ISEMP also ensures that monitoring programs can address large-scale management objectives (resulting largely from the ESA) through these local efforts. While the ISEMP maintains a regional focus it also returns the necessary information to aid in management at the smaller spatial scales (individual projects) where manipulations (e.g., habitat restoration actions) actually occur.

The work captured in this report is a component of the overall Integrated Status and Effectiveness Monitoring Program, and while it stands alone as an important contribution to the management of anadromous salmonids and their habitat, it also plays a key role within ISEMP. Each component of work within ISEMP is reported on individually, as is done so here, and in annual and triennial summary reports that present all of the overall project components in their programmatic context and shows how the data and tools developed can be applied to the development of regionally consistent, efficient and effective Research, Monitoring and Evaluation.

\section{Juvenile outmigation study}

The primary goal of this study is to provide long-term monitoring information about the juvenile life history characteristics and productivity of ESA listed spring Chinook salmon and steelhead in the Entiat River basin. Specifically, the study primarily utilizes migrant traps and to some extent seines and angling to capture juveniles in order to quantify abundance, measure physical characteristics, and tag individuals to assess migration timing and survival. Once obtained this data is incorporated into a regional database that is utilized by area resource managers to compare attributes both within and among populations located in the Upper Columbia River basin. The final outcome of this study is to guide scientifically sound decisions regarding the future management of these imperiled species. This document reports the data collected from juvenile collection operations from January 1, 2008 through November 20, 2008.

\section{Snorkel surveys}

This is the fourth annual progress report to Bonneville Power Administration for the snorkel surveys conducted in the Entiat River as related to long-term effectiveness monitoring of restoration programs in this watershed. 
In 2005, the Cascadia Conservation District (CCD) in association with the Entiat Watershed Planning Unit (EWPU) initiated a large-scale restoration program in a $2000 \mathrm{~m}$ section of the Entiat River watershed, known as the "Entiat Bridge-to-Bridge Project". This is a phased program that will, over a several year period, incorporate a suite of stream restoration measures that include in-stream habitat structures, reconnection of relict stream channels, and riparian plantings. This project has since grown to include the entire Entiat River, however focusing on the area downstream of river kilometer (rkm) 35. The restoration efforts in the Entiat River are intended to provide complexity to the river system and a positive benefit for aquatic organisms including ESA listed fish species.

The Entiat River Effectiveness Monitoring Study plans to evaluate fish utilization of instream habitat modifications within the Entiat River. The U.S. Fish and Wildlife Service's Mid-Columbia River Fishery Resource Office (MCRFRO) is conducting the snorkeling component of the Entiat Effectiveness Monitoring Study that will evaluate fish habitat utilization associated with in-stream restoration work planned for the lower Entiat River.

The objective of this study is to monitor the fish habitat utilization of planned in-stream restoration efforts in the Entiat River by conducting pre- and post-construction snorkel surveys at selected treatment and control sites.

\section{Steelhead redd surveys}

The primary goal of this study is to enumerate steelhead redds and describe distribution of those redds in the main Entiat River.

\section{Study Area}

The Entiat River watershed originates from 11 glaciers and snowfields in the Cascade Mountains and flows southeast approximately $69 \mathrm{~km}$ to join the Columbia River at river kilometer (Rkm) 778 (CCCD 2004, Mullan et al. 1992). The Entiat watershed is bordered by the Entiat Mountains to the southwest and the Chelan Mountains to the northeast and drains approximately $1,085 \mathrm{~km}^{2}$. The topography is steep with unstable erodible soils and vegetation types varying from semi-arid shrub steppe near the confluence with the Columbia River to temperate forests and alpine meadows in the headwaters.

Past glacial activity has shaped the Entiat River valley by creating a U-shaped valley upstream of a terminal moraine at rkm 26.1 and V shaped valley downstream (Mullan et al. 1992). The present upstream limit to anadromy is at Entiat Falls rkm 54.4.

The Mid-Columbia River Fishery Resource Office has been operating a rotary screw trap in the Entiat River at (rkm) 11 adjacent to the Entiat National Fish Hatchery (ENFH) since 2003, and has captured juvenile fish at other sites within the Entiat Basin for PIT tagging since 2005. In addition to the legacy collection sites, the MCRFRO added another rotary screw trap at rkm 2 for the 2007 field season (Figure 1). 
The snorkel survey study reach is located in Entiat River between the rkm 0.5 to 34.4 and the Bridge to Bridge section is located between rkm 5.2 to 7.4 (Figure 2). Steelhead redd surveys study reach is between rkm 1.1 and 44.2 (Figure 2).

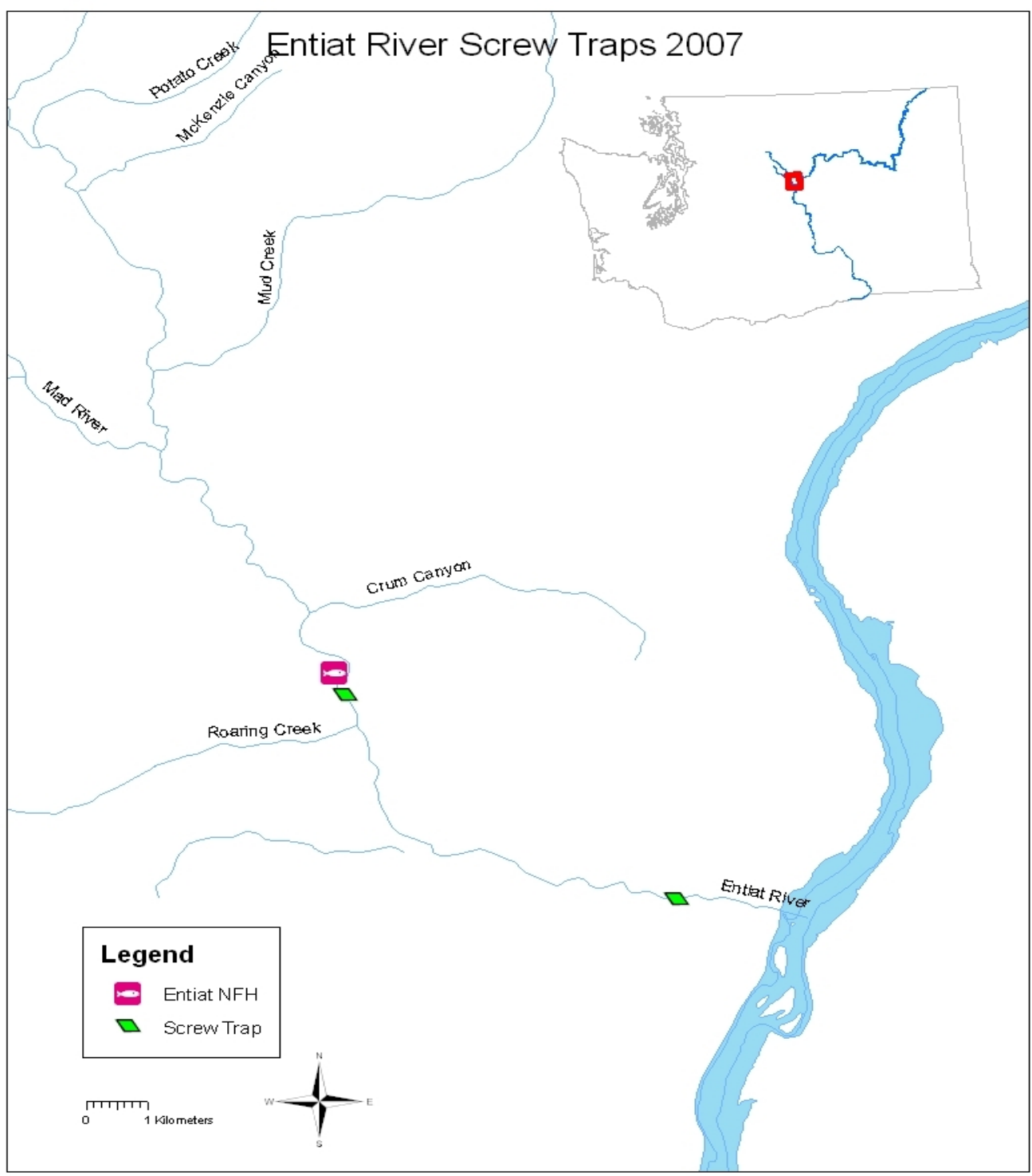

Figure 1. Study reach map of the Entiat River watershed with the juvenile rotary screw trap locations. 


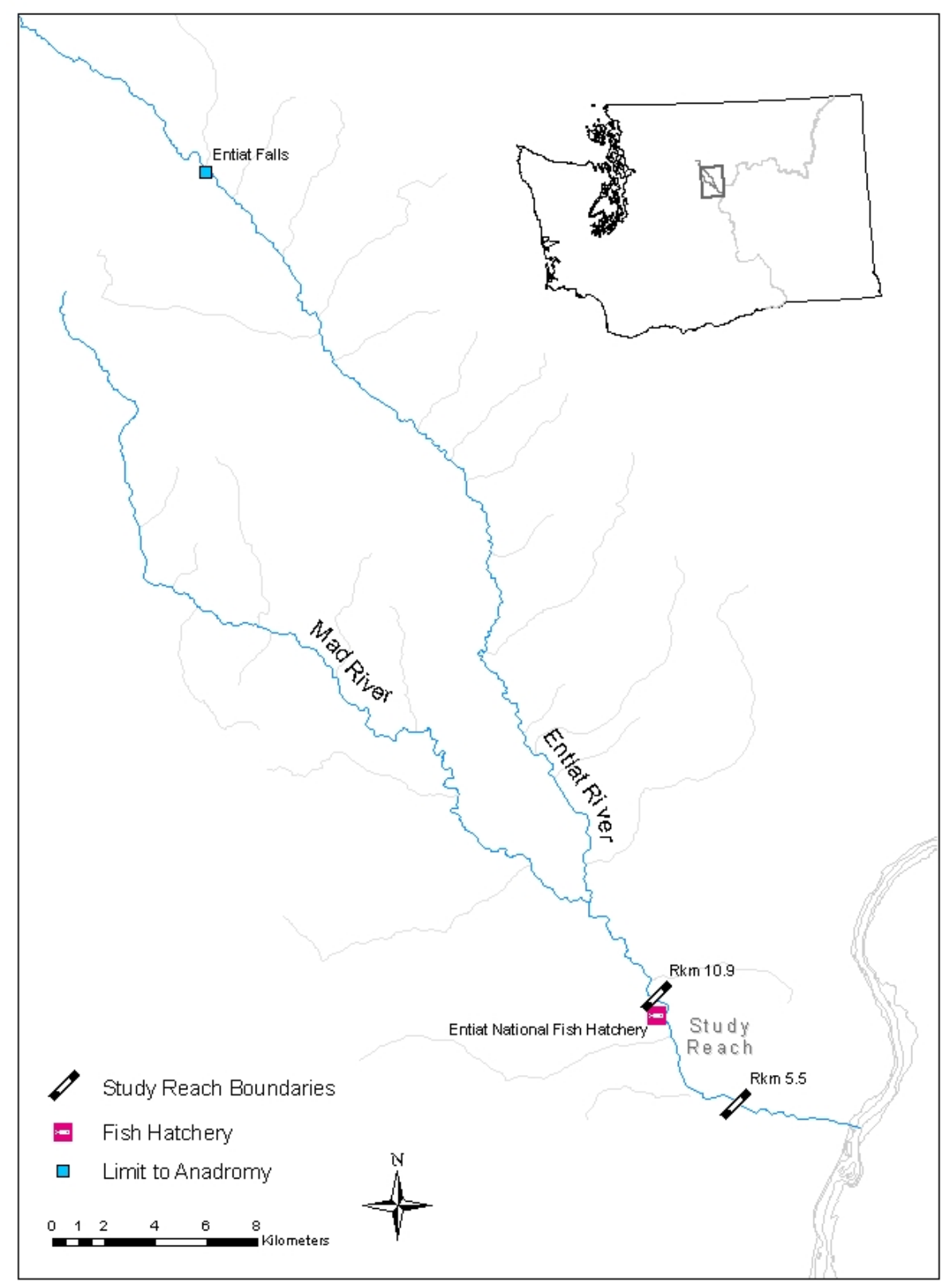

Figure 2. Study reach map of the Entiat River watershed with snorkel survey area from rkm 0.5 to 34.4. Steelhead surveys are located from rkm 1.1 to 44.2.

The Entiat River watershed supports seven native and one introduced salmonid species which include spring and summer Chinook salmon Oncorhynchus tshawytscha, steelhead and resident rainbow trout $O$. mykiss gairdneri, sockeye salmon $O$. nerka, 
westslope cutthroat trout $O$. clarki lewisi, coho salmon $O$. kisutch, mountain whitefish Prosopium williamsoni, bull trout Salvelinus confluentus, and introduced eastern brook trout $S$. fontinalis. Other fish species include chiselmouth Acrocheilus alutaceus, northern pikeminnow Ptychocheilus oregonensis, largescale sucker Catostomus macrocheilus, bridgelip sucker $C$. columbianus, speckled dace Rhinichthys osculus, longnose dace $R$. cataractae, redside shiner Richardsonius balteatus, sculpin Cottus spp., three-spined stickleback Gasterosteus aculeatus and Pacific lamprey Entosphenus tridentatus. (Mullan et al 1992, CCCD 2004, Wydoski and Whitney 2003).

\section{Methods-rotary screw trap}

\section{Rotary screw trap operation}

Juvenile trapping and methodology are discussed annually amongst a variety of agencies conducting trapping programs upon completion of the field season. The results of these previous discussions resulted in a basin-wide applied trapping protocol (Tussing, 2008). Two modified $5 \mathrm{ft}$. diameter rotary screw traps manufactured by EG Solutions Inc. were used during this study to capture downstream migrating salmonids. The traps were retrofitted with pontoons from $8 \mathrm{ft}$. style screw traps to facilitate better floatation and safety in higher flow regimes. Additionally a debris door was placed on each trap cone and each trap was outfitted with a spray bar to pressure wash away accumulated algae that clogs the cone screen. Trap operations followed operational permit guidelines as per Chelan County Shoreline Management Act (file\# SE 06-016 US Fish and Wildlife Service Fish Enhancement letter dated August 16, 2006), WDFW Temporary Use Permit (dated 11/27/07), and two Hydraulic Project Approvals (log\#ST-F8213-01, upper trap dated 3/18/08 and control\#112413-1, lower trap, dated 11/21/06). Assembled traps were lowered into the river via a boom truck and attached to $1 / 4$ inch aircraft cable that was anchored upstream to the bases of large cottonwood trees. A bridge at the upper trap site and a cross cable at the lower trap site suspended the anchor cable above the stream from the anchor point to the trap. A system of winches and pulleys were utilized throughout the season to guide the trap within the river as flow regimes changed. Traps were assigned fixed positions based on flow. These positions were strictly adhered to, in order to pool and statistically strengthen screw trap efficiencies. The traps operated seven days a week from March through November with allowances for some events. If possible, traps were operated 24 hours a day, however, during spring high flows and increased debris loads the traps were operated from twilight to after sunrise. At times during extreme discharge events the traps were pulled and taken out of operation until such time that river conditions warranted reinitiating operations.

Fish handling

Fish handling procedures were conducted in accordance with WDFW Scientific Collection Permits \#08-147-151 (dated 4/25/08), NOAA Permit 119 modification 2 (F/NWR3 dated 4/10/08 and F/NWR/2006/04329 dated 9/18/06) and USFWS Subpermit No. MCRFO-11 (dated 4/23/07). 
At least once a day, juvenile fish were transported from the live box of each trap into 5 gallon buckets for tagging and biological sampling. The buckets were equipped with aerators, and a light salt $(\mathrm{NaCl})$ solution (1 tbs/gal.) was added to minimize stress during transport and holding. The fish were transported to the ENFH, where a permanent, on-site electronic fish handling/tagging station has been built.

All fish species collected for biological sampling were anesthetized in a water bath with a measured amount of tricaine (MS-222) buffered with sodium bicarbonate to stage 3 or 4 as described in the Stages of Anesthesia by Summerfelt and Smith (1990). Small groups of fish were anesthetized at any one time during daily handling to reduce the chance of incidental mortality from anesthetic overdose. All fish were identified to species with the exception of sculpin, dace, sucker, and whitefish. Attempts were made to further break Chinook sub-yearling juveniles into run categories (spring, summer and unknown run). In previous years, spring and summer run designation was determined by a late summer nadir in Chinook captures. Chinook captured prior to the nadir were identified as summer run, and those captured after were called spring Chinook. In February of 2008, a PIT tag interrogation site was installed and operational on the lower Entiat River. The data from this interrogation site clearly illustrated that our previous attempts to identify subyearling Chinook were inadequate. Sub-yearling Chinook not clearly identifiable by length at date criteria, were designated as wild Chinook of unknown run to prevent misidentification.

In addition to species identification and Chinook run classification, both steelhead and Chinook were further ascribed to a life history stage as either fry $(<60 \mathrm{~mm})$, parr $(>60 \mathrm{~mm}$ and distinctive parr marks), transitional ( $>60 \mathrm{~mm}$ silver sheen, faint parr marks) or smolt ( $>60 \mathrm{~mm}$ silver sheen with absent parr marks with possible black tipped caudal). Stage classification may provide a useful metric to gauge migratory readiness in juveniles and may help serve to separate resident "rainbow" from the migratory steelhead juveniles.

A minimum of 30 fish per species and life stage were measured to the nearest millimeter of fork length and all salmonids greater than $60 \mathrm{~mm}$ were weighed to the nearest tenth of a gram. After handling, all juveniles were allowed to fully recover prior to release. Nontagged juveniles were released approximately 400 meters downstream from the trap after a minimum one hour of recovery time.

PIT tagging of juvenile Chinook, steelhead, and bull trout follows the procedures and file submission requirements outlined by Pacific State Marine Fisheries Commission PIT Tag Information System (PTAGIS) in addition to juvenile PIT tagging procedures described in the ISEMP Upper Columbia River Basin Protocol (TerrAqua, 2007). Wild juvenile Chinook, coho, steelhead, cutthroat and bull trout greater than $60 \mathrm{~mm}$ of fork length were tagged using a disinfected hollow needle to insert the PIT tag (TX1411SST $134.2 \mathrm{kHz}$ tags $12.5 \mathrm{~mm} / 0.102 \mathrm{gm}$ ) into the abdominal cavity. ISEMP supplied PIT tags for ESA listed spring Chinook and steelhead, Chelan County PUD provided tags for bull trout and the USFWS supplied PIT tags for cutthroat and Coho. All PIT tagged juveniles are measured to the nearest millimeter $(\mathrm{mm})$ in fork length and weighed to the nearest tenth of a gram (gm) and any injuries noted. Juveniles are not PIT tagged if determined to 
have a recent or substantial injury that may become aggravated through tagging. PIT tagged juveniles were generally held $24 \mathrm{hrs}$ at ENFH to monitor survival and tag retention. A maximum of 72 hours hold time was instituted on all tagged fish.

\section{Data entry}

All individual fish data entry utilized the P3 program from PTAGIS. P3 is a data entry application program required to collect and submit information about marked or recaptured fish with a PIT tag in the Columbia River Basin. USFWS utilized this program as a tool to enter all fish information regardless of whether the fish was marked with a PIT tag. P3 serves as a Microsoft Access ${ }^{\mathrm{TM}}$ overlay which allows communication with peripheral devices. USFWS peripheral devices included a Destron Fearing FS2001ISO transceiver/antenna for reading PIT tags, a GTCO Calcomp DrawSlate VI digitizing board and a GSE 350 electronic balance for automating data entry into a laptop computer. Utilizing a custom Access ${ }^{\mathrm{TM}}$ database designed by Environmental Data Services (contact: Steve Rentmeester), P3 generated files could then be automatically parsed into the ISEMP database. The original P3 file was left intact and subsequently uploaded to PTAGIS. From this database, PIT tag information is parsed and housed for use by researchers throughout the Columbia River Basin.

\section{Remote capture for PIT tagging}

A large segment of PIT tagged fish are collected via rotary screw traps. However, the number of juvenile fish of minimum length $(>60 \mathrm{~mm})$ to be PIT tagged at the trap is generally short of the recommended 5,000 tagged steelhead/rainbow trout and 5,000 spring Chinook salmon needed from each sub-basin to effectively estimate life-stage survival rates (Hillman 2006). In addition, the rotary screw traps capture only currently migrating juveniles. The data obtained via PIT tag monitoring represent movement and survival outside of the Entiat Basin, as these juveniles migrate through the Columbia River hydro-corridor to the ocean. To increase the number of tagged fish and to improve information regarding within basin survival and migration timing, non-migratory juvenile spring Chinook and steelhead rearing within the watershed were targeted for capture and subsequent tagging. As part of a collaborative effort with the Washington Department of Fish and Wildlife (WDFW), Trout Unlimited, and the Wenatchee Valley Fly Fishing Club, "remote tagging" was conducted throughout the Entiat River and its main tributary, the Mad River, during the months of July -September.

Remote tagged steelhead and Chinook salmon were primarily caught using angling and snorkel herding. Angling capture consisted of single barbless flies (size 14 and smaller) on light fly fishing gear. Snorkel herding utilized a team of in-stream snorkelers and a beach seine net to target and capture juvenile salmonids. Remote capture and PIT tagging activities were limited to temperature regimes below $17^{\circ} \mathrm{C}$. Collected juveniles were tagged and released near their capture location. A proportion of remote tagged fish were held for 24 hours in mid-stream liveboxes to monitor tag retention and survival.

Genetic and scale sampling

Throughout the migration, a subset of captured bull trout, cutthroat trout, yearling and sub-yearling Chinook salmon and steelhead juveniles were sampled for genetic and age 
analysis, as per the Upper Columbia River Monitoring Strategy (Hillman 2006). This type of sampling is non-lethal. Genetic sampling involved taking a small clip of tissue from either the ventral (steelhead, cutthroat \& spring Chinook) or caudal fin (bull trout) and scales were collected from steelhead only. Steelhead tissue and scales were sent to the WDFW Office in Wenatchee and Chinook, cutthroat and bull trout tissues were sent to the Region 1 USFWS genetics lab for future analysis.

Screw trap efficiency

A portion of the collected Chinook and steelhead were used to estimate trap capture efficiency. Captured fish were pooled for up-to 72 hours and released upstream of the capture origin. All fish used for efficiency trials were either PIT tagged ( $>60 \mathrm{~mm}$ FL) or dye marked $(<60 \mathrm{~mm}$ FL) with Bismark brown. Marked fish were placed in a live box located at ENFH for holding ( $<72$ hrs) prior to release. Marked fish were transported to release sites using 5 gallon buckets with aerators to minimize stress. Juvenile fish used for efficiency trials were released at twilight upstream of each trap. The release location for the upper trap was located primarily at rkm 18 (Mad River road bridge) for the upper trap and rkm 2.3 (Keystone Ranch private bridge) for the lower trap site. PIT tagged recaptured fish were subsequently re-measured and released to document growth rates since time of first capture. Fish recaptured at the same trap twice were removed from the daily catch estimate.

\section{Water temperature and discharge}

Water temperatures were verified with analog instruments to verify accuracy. Discharge was monitored by a USGS station number 12452990 located at rkm 2.3.

\section{Trap operation time}

\section{Results-rotary screw trap}

From March 3 through November 20, 2008 there were 263 days available to trap, of these a total of 32 days (12\%) were lost to rotary screw trap capture (Table 4). Extreme discharge, flood events, and an over abundance of debris were the main contributors for days lost to trapping. Irregular trap failures and breakdowns accounted for only a small portion of non-sampling days.

Table 1. Rotary screw trap operation from March through November 2008.

\begin{tabular}{|l|c|c|c|}
\hline Month & $\begin{array}{c}\text { Days } \\
\text { Available }\end{array}$ & $\begin{array}{c}\text { Days in } \\
\text { Operation }\end{array}$ & $\begin{array}{c}\text { Days } \\
\text { Pulled }\end{array}$ \\
\hline March & 29 & 29 & 0 \\
April & 30 & 30 & 0 \\
May & 31 & 15 & 16 \\
June & 30 & 22 & 8 \\
July & 31 & 30 & 1 \\
August & 31 & 31 & 0 \\
September & 30 & 29 & 1 \\
October & 31 & 30 & 1 \\
November & 20 & 15 & 5 \\
\hline
\end{tabular}




\section{Juvenile emigration}

During this study period, the month of April proved the most productive capture and tagging month for both juvenile steelhead and yearling Chinook (Table 2 and 3). Peak smolt migration combined for both traps was April $15^{\text {th }}$ for wild spring Chinook (843), and May $6^{\text {th }}$ (340) for juvenile steelhead.

Table 2. Capture and PIT tag totals of wild juveniles from the lower Entiat River smolt trap (rkm 2) from March through November of 2008.

\begin{tabular}{|c|c|c|c|c|c|c|}
\hline Month & Species & Caught & $\begin{array}{c}\text { PIT } \\
\text { Tagged }\end{array}$ & $\begin{array}{c}\text { Avg. } \\
\text { Length }\end{array}$ & $\begin{array}{c}\text { Avg. } \\
\text { Weight }\end{array}$ & $\begin{array}{c}\mathrm{K} \\
\text { factor }\end{array}$ \\
\hline \multirow[t]{7}{*}{ March } & Spring Chinook & 300 & 252 & 98.88 & 9.66 & 0.9554 \\
\hline & Summer Chinook & 31 & 0 & 41.81 & --- & --- \\
\hline & Chinook unknown run & 0 & 0 & --- & --- & --- \\
\hline & Steelhead & 7 & 6 & 144.17 & 32.97 & 0.9613 \\
\hline & Coho & 3 & 0 & 146.00 & 34.47 & 1.0420 \\
\hline & Bull Trout & 1 & 1 & 186.00 & 55.50 & 0.8600 \\
\hline & Cutthroat & 0 & 0 & --- & --- & --- \\
\hline \multirow[t]{7}{*}{ April } & Spring Chinook & 1995 & 1574 & 103.16 & 10.89 & 0.9639 \\
\hline & Summer Chinook & 16 & 0 & 40.81 & --- & --- \\
\hline & Chinook unknown run & 0 & 0 & --- & --- & --- \\
\hline & Steelhead & 585 & 515 & 154.11 & 40.43 & 0.9430 \\
\hline & Coho & 2 & 0 & 138.00 & 26.85 & 0.9890 \\
\hline & Bull Trout & 2 & 2 & 195.50 & 69.70 & 0.9166 \\
\hline & Cutthroat & 0 & 0 & --- & --- & --- \\
\hline \multirow[t]{7}{*}{ May } & Spring Chinook & 333 & 254 & 101.91 & 10.51 & 0.9612 \\
\hline & Summer Chinook & 2 & 0 & 54.50 & --- & --- \\
\hline & Chinook unknown run & 0 & 0 & --- & --- & --- \\
\hline & Steelhead & 732 & 629 & 171.13 & 48.98 & 0.9349 \\
\hline & Coho & 4 & 1 & 123.75 & 17.45 & 0.8993 \\
\hline & Bull Trout & 40 & 39 & 156.21 & 33.43 & 0.8502 \\
\hline & Cutthroat & 0 & 0 & --- & --- & --- \\
\hline \multirow[t]{7}{*}{ June } & Spring Chinook & 27 & 24 & 70.14 & 3.45 & 0.9800 \\
\hline & Summer Chinook & 1687 & 0 & 41.46 & --- & --- \\
\hline & Chinook unknown run & 0 & 0 & --- & --- & --- \\
\hline & Steelhead & 6 & 3 & 140.67 & 31.37 & 1.1195 \\
\hline & Coho & 9 & 0 & 60.56 & 6.05 & 0.9745 \\
\hline & Bull Trout & 8 & 7 & 159.14 & 43.61 & 1.0608 \\
\hline & Cutthroat & 0 & 0 & 0.00 & 0.00 & $\mathrm{n} / \mathrm{a}$ \\
\hline \multirow[t]{5}{*}{ July } & Spring Chinook & 297 & 271 & 81.49 & 5.69 & 0.9999 \\
\hline & Summer Chinook & 1924 & 0 & 56.94 & --- & --- \\
\hline & Chinook unknown run & 0 & 0 & --- & --- & --- \\
\hline & Steelhead & 31 & 12 & 191.17 & 77.43 & 1.0717 \\
\hline & Coho & 70 & 0 & 77.36 & 5.52 & 1.0570 \\
\hline
\end{tabular}




\begin{tabular}{|l|l|l|l|l|l|} 
Bull Trout & 3 & 1 & 195.00 & 73.00 & 0.9845 \\
\hline Cutthroat & 1 & 1 & 211.00 & 82.80 & 0.8814 \\
\hline
\end{tabular}

\begin{tabular}{|l|l|r|r|r|r|r|}
\multirow{4}{*}{ August } & Spring Chinook & 2 & 2 & 94.50 & 9.65 & 1.1500 \\
\cline { 2 - 7 } & Summer Chinook & 1244 & 0 & 73.06 & 4.47 & 1.0162 \\
\cline { 2 - 7 } & Chinook unknown run & 28 & 18 & 100.13 & 12.39 & 1.1768 \\
\cline { 2 - 7 } & Steelhead & 150 & 131 & 178.40 & 66.44 & 1.0583 \\
\cline { 2 - 7 } & Coho & 9 & 2 & 87.67 & 7.10 & 1.0467 \\
\cline { 2 - 7 } & Bull Trout & 4 & 2 & 188.50 & 69.65 & 1.0243 \\
\hline & Cutthroat & 7 & 241.00 & 224.81 & 0.9958 \\
\hline
\end{tabular}

\begin{tabular}{|l|l|r|r|r|r|r|}
\hline \multirow{3}{*}{ September } & Spring Chinook & 0 & 0 & --- & --- & --- \\
\cline { 2 - 7 } & Summer Chinook & 115 & 0 & 73.88 & 4.36 & 1.0316 \\
\cline { 2 - 7 } & Chinook unknown run & 661 & 575 & 84.58 & 6.85 & 1.0570 \\
\hline Steelhead & 260 & 240 & 177.49 & 61.36 & 1.0238 \\
\cline { 2 - 7 } & Coho & 16 & 16 & 97.06 & 10.45 & 1.1239 \\
\hline & Bull Trout & 5 & 4 & 238.75 & 137.55 & 0.9957 \\
\hline & Cutthroat & 4 & 237.25 & 153.58 & 1.0136 \\
\hline
\end{tabular}

\begin{tabular}{|l|l|r|r|r|r|r|}
\multirow{4}{*}{ October } & Spring Chinook & 0 & 0 & --- & --- & --- \\
\cline { 2 - 7 } & Summer Chinook & 0 & 0 & --- & -- & --- \\
\cline { 2 - 7 } & Chinook unknown run & 1136 & 777 & 85.94 & 6.84 & 1.0386 \\
\hline & Steelhead & 110 & 94 & 145.91 & 43.23 & 1.0034 \\
\cline { 2 - 7 } & Coho & 10 & 10 & 101.20 & 11.69 & 1.1012 \\
\cline { 2 - 7 } & Bull Trout & 0 & 5 & 303.00 & 327.56 & 0.9792 \\
\cline { 2 - 7 } & Cutthroat & 0 & 206.00 & 97.30 & 1.1130 \\
\hline
\end{tabular}

\begin{tabular}{|l|l|r|r|r|r|r|}
\cline { 2 - 6 } November & Spring Chinook & 0 & 0 & --- & --- & --- \\
\cline { 2 - 7 } & Summer Chinook & 0 & 0 & --- & -- & --- \\
\cline { 2 - 7 } & Chinook unknown run & 1902 & 1642 & 91.29 & 8.20 & 1.0364 \\
\cline { 2 - 7 } Steelhead & 406 & 367 & 123.94 & 25.97 & 1.0067 \\
\cline { 2 - 7 } & Coho & 22 & 21 & 104.81 & 12.30 & 1.0428 \\
\hline & Bull Trout & 28 & 23 & 224.96 & 123.60 & 1.0013 \\
\hline Cutthroat & 1 & 1 & 206.00 & 97.30 & 1.1130 \\
\hline
\end{tabular}

Table 3. Capture and PIT tag totals of wild juveniles from upper Entiat River smolt trap (rkm 11.0) March through November, 2008.

\begin{tabular}{|c|c|c|c|c|c|c|}
\hline Month & Species & Caught & $\begin{array}{c}\text { PIT } \\
\text { Tagged } \\
\end{array}$ & $\begin{array}{c}\text { Avg. } \\
\text { Length }\end{array}$ & $\begin{array}{c}\text { Avg. } \\
\text { Weight }\end{array}$ & $\begin{array}{c}\mathrm{K} \\
\text { factor }\end{array}$ \\
\hline \multirow[t]{7}{*}{ March } & Spring Chinook & 703 & 691 & 97.98 & 8.92 & 0.9254 \\
\hline & Summer Chinook & 4 & 0 & 39.00 & --- & --- \\
\hline & Chinook unknown run & 0 & 0 & --- & --- & --- \\
\hline & Steelhead & 5 & 4 & 146.25 & 34.75 & 0.9166 \\
\hline & Coho & 1 & 0 & 142.00 & 29.00 & 1.0130 \\
\hline & Bull Trout & 0 & 0 & --- & --- & --- \\
\hline & Cutthroat & 0 & 0 & --- & --- & --- \\
\hline
\end{tabular}


April

\begin{tabular}{|l|r|r|r|r|r|}
\hline Spring Chinook & 3448 & 3324 & 103.83 & 11.15 & 0.9607 \\
\hline Summer Chinook & 62 & 0 & 39.86 & --- & --- \\
\hline Chinook unknown run & 0 & 0 & --- & --- & --- \\
\hline Steelhead & 516 & 488 & 175.79 & 52.47 & 0.9173 \\
\hline Coho & 7 & 1 & 120.57 & 17.27 & 0.9527 \\
\hline Bull Trout & 2 & 2 & 177.00 & 45.45 & 0.7381 \\
\hline Cutthroat & 0 & 0 & --- & --- & --- \\
\hline
\end{tabular}

May

\begin{tabular}{|l|r|r|r|r|r|}
\hline Spring Chinook & 488 & 473 & 103.48 & 11.15 & 0.9808 \\
\hline Summer Chinook & 56 & 0 & 45.51 & --- & -- \\
\hline Chinook unknown run & 0 & 0 & --- & --- & --- \\
\hline Steelhead & 970 & 831 & 174.03 & 50.79 & 0.9276 \\
\hline Coho & 11 & 0 & 115.73 & 17.51 & 0.9526 \\
\hline Bull Trout & 18 & 16 & 161.00 & 36.29 & 0.8309 \\
\hline Cutthroat & 0 & 0 & --- & --- & --- \\
\hline
\end{tabular}

June

\begin{tabular}{|l|r|r|r|r|r|}
\hline Spring Chinook & 10 & 9 & 78.89 & 5.54 & 0.9945 \\
\hline Summer Chinook & 1344 & 0 & 40.97 & --- & --- \\
\hline Chinook unknown run & 0 & 0 & --- & --- & --- \\
\hline Steelhead & 11 & 5 & 149.40 & 38.42 & 1.1200 \\
\hline Coho & 2 & 0 & 112.62 & 15.82 & 0.9658 \\
\hline Bull Trout & 9 & 6 & 154.50 & 39.20 & 1.0317 \\
\hline Cutthroat & 0 & 0 & --- & --- & --- \\
\hline
\end{tabular}

July

\begin{tabular}{|l|r|r|r|r|r|}
\hline Spring Chinook & 112 & 106 & 86.09 & 6.77 & 1.0030 \\
\hline Summer Chinook & 1272 & 0 & 50.07 & 6.05 & 0.9933 \\
\hline Chinook unknown run & 0 & 0 & --- & --- & --- \\
\hline Steelhead & 74 & 13 & 170.38 & 54.95 & 1.0247 \\
\hline Coho & 2 & 0 & 63.50 & 5.40 & 1.0950 \\
\hline Bull Trout & 0 & 0 & --- & --- & --- \\
\hline Cutthroat & 0 & 0 & --- & --- & --- \\
\hline
\end{tabular}

August

\begin{tabular}{|l|r|r|r|r|r|}
\hline Spring Chinook & 8 & 7 & 97.00 & 10.04 & 1.0954 \\
\hline Summer Chinook & 1039 & 0 & 72.23 & 4.90 & 1.0586 \\
\hline Chinook unknown run & 58 & 58 & 98.33 & 11.51 & 1.2036 \\
\hline Steelhead & 215 & 189 & 166.51 & 54.33 & 1.0484 \\
\hline Coho & 0 & 0 & --- & --- & --- \\
\hline Bull Trout & 3 & 3 & 187.33 & 69.53 & 0.9723 \\
\hline Cutthroat & 7 & 7 & 199.14 & 77.47 & 0.9644 \\
\hline
\end{tabular}

\begin{tabular}{|l|l|r|r|r|r|r|}
\hline \multirow{4}{*}{ September } & Spring Chinook & 0 & 0 & --- & --- & --- \\
\cline { 2 - 7 } & Summer Chinook & 88 & 0 & 70.43 & 3.96 & 1.0106 \\
\cline { 2 - 7 } & Chinook unknown run & 232 & 191 & 84.01 & 6.93 & 1.0801 \\
\cline { 2 - 7 } & Steelhead & 127 & 116 & 167.61 & 52.11 & 1.0275 \\
\hline Coho & 1 & 1 & 102.00 & 12.00 & 1.1310 \\
\hline Bull Trout & 1 & 1 & 216.00 & 82.50 & 0.8186 \\
\hline Cutthroat & 4 & 4 & 213.00 & 100.43 & 1.0364 \\
\hline
\end{tabular}


October

\begin{tabular}{|l|r|r|r|r|r|}
\hline Spring Chinook & 0 & 0 & --- & --- & --- \\
\hline Summer Chinook & 0 & 0 & --- & --- & --- \\
\hline Chinook unknown run & 1044 & 982 & 89.86 & 8.11 & 1.0584 \\
\hline Steelhead & 106 & 103 & 158.00 & 49.74 & 0.9901 \\
\hline Coho & 3 & 2 & 101.00 & 11.55 & 1.1190 \\
\hline Bull Trout & 11 & 8 & 225.63 & 122.64 & 0.9525 \\
\hline Cutthroat & 3 & 3 & 329.00 & 429.57 & 1.0913 \\
\hline
\end{tabular}

November

\begin{tabular}{|l|r|r|r|r|r|}
\hline Spring Chinook & 0 & 0 & --- & --- & --- \\
\hline Summer Chinook & 0 & 0 & --- & --- & --- \\
\hline Chinook unknown run & 1389 & 1346 & 91.74 & 8.29 & 1.0355 \\
\hline Steelhead & 223 & 215 & 142.31 & 33.22 & 0.9738 \\
\hline Coho & 2 & 2 & 114.00 & 15.30 & 1.0205 \\
\hline Bull Trout & 39 & 38 & 207.66 & 92.19 & 0.9614 \\
\hline Cutthroat & 2 & 2 & 268.00 & 168.95 & 0.8181 \\
\hline
\end{tabular}

Table 4. Cumulative capture totals of wild juveniles from both Entiat River smolt traps from March through November, 2008.

\begin{tabular}{|l|c|c|c|}
\hline Species & $\begin{array}{l}\text { Lower Entiat } \\
\text { Smolt Trap } \\
\text { (Rkm 2.0) }\end{array}$ & $\begin{array}{l}\text { Upper Entiat } \\
\text { Smolt Trap } \\
\text { (Rkm 11.0) }\end{array}$ & Totals \\
\hline Spring Chinook & 2954 & 4769 & 7723 \\
\hline Summer Chinook & 5019 & 3865 & 8884 \\
\hline Chinook unknown run & 3727 & 2723 & 6450 \\
\hline Steelhead & 2287 & 2247 & 4534 \\
\hline Coho & 145 & 29 & 174 \\
\hline Bull Trout & 99 & 83 & 182 \\
\hline Cutthroat & 13 & 16 & 29 \\
\hline
\end{tabular}

\section{Remote tagging operations}

A total of 760 wild juvenile salmonids were tagged at remote locations spread throughout the Entiat and Mad River watersheds. The species composition of the 760 remotely PIT tagged wild salmonids consisted of 674 steelhead, 65 Chinook, 11 Coho, and 10 cutthroat. Angling was the most effective method to catch steelhead (631 total - 94\%), while Chinook dominated the catch from snorkel-herding (58 total - 94\%). By stream habitat type, angling proved to be the most productive method in boulder dominated riffles and steeper gradients such as those often encountered in the lower reaches of the Mad River. Conversely, snorkel-herding and electro-fishing tactics proved a reliable capture method in low gradient reaches, off channel habitat, and debris jams such as those found at various locations in the main stem Entiat River. 


\section{Trap efficiencies}

A total of 17 viable rotary screw trap efficiency trials were conducted on the Entiat River smolt traps. There were other trials conducted during the study period, but these results were thrown out due to fish health concerns, low release numbers, or incorrect trap position. The upper rotary screw trap had nine suitable trials conducted with an average efficiency estimated at $40.29 \%$ combined for Chinook and steelhead (Table 5). The lower smolt trap had 8 viable trials with an average capture efficiency estimated at 7.68\% (Table 6). All trap efficiency trials utilized PIT tagged transitional or smolt juveniles which were released after dusk to ensure individuals in the mark group were migratory.

Table 5. Upper Entiat River (rkm 11.0) smolt trap efficiency trial results.

\begin{tabular}{|c|c|r|}
\hline \multicolumn{2}{|c|}{$\begin{array}{c}\text { Discharge } \\
\text { Release Date }\end{array}$} & $\begin{array}{c}\text { Estimated } \\
\text { Efficiency }\end{array}$ \\
\hline $3 / 13 / 2008$ & 198 & $54.023 \%$ \\
\hline $3 / 20 / 2008$ & 183 & $48.649 \%$ \\
\hline $4 / 3 / 2008$ & 155 & $49.650 \%$ \\
\hline $4 / 14 / 2008$ & 236 & $37.793 \%$ \\
\hline $4 / 18 / 2008$ & 278 & $46.667 \%$ \\
\hline $4 / 25 / 2008$ & 250 & $40.291 \%$ \\
\hline $5 / 2 / 2008$ & 327 & $36.000 \%$ \\
\hline $5 / 6 / 2008$ & 519 & $31.429 \%$ \\
\hline $5 / 9 / 2008$ & 771 & $18.182 \%$ \\
\hline
\end{tabular}

Table 6. Lower Entiat River (rkm 2.0) smolt trap efficiency trial results.

\begin{tabular}{|c|c|r|}
\hline Release Date & \multicolumn{1}{c}{$\begin{array}{c}\text { Discharge } \\
\text { (CFS) }\end{array}$} & $\begin{array}{c}\text { Estimated } \\
\text { Efficiency }\end{array}$ \\
\hline $3 / 31 / 2008$ & 156 & $3.390 \%$ \\
\hline $4 / 9 / 2008$ & 159 & $1.242 \%$ \\
\hline $4 / 10 / 2008$ & 160 & $4.065 \%$ \\
\hline $4 / 11 / 2008$ & 168 & $5.357 \%$ \\
\hline $4 / 14 / 2008$ & 236 & $14.881 \%$ \\
\hline $4 / 25 / 2008$ & 250 & $11.594 \%$ \\
\hline $4 / 30 / 2008$ & 327 & $14.545 \%$ \\
\hline $5 / 3 / 2008$ & 344 & $6.383 \%$ \\
\hline
\end{tabular}

\section{ATM/PTAGIS upload}

All data was uploaded into the Automated Template Module (ATM) for rotary screw trap smolt sampling on a weekly basis through May. However, the release of ATM v2.0

proved a difficult transition for the USFWS smolt trap project. Continual errors in P3 file 
upload and PIT code recapture types made the database unusable until corrections were made. Continual updates, fixes and beta testing were conducted throughout the season and the ATM is progressing towards a database with analysis utility. The last release was sent out on December $16^{\text {th }}$, however this version has not been tested, and the data from the 2008 season has not been entered into the ATM. The USFWS developed a Microsoft Access database that was used in lieu of the ATM for permit and report writing obligations. Continued beta testing of the ATM prior to the start of the 2009 season should allow for a real-time data upload into the ATM. All P3 files were uploaded into the PTAGIS database on a bi-weekly basis. All final uploads into the PTAGIS database were completed on December $9^{\text {th }}$, 2008.

\section{Discussion-rotary screw trap}

\section{Rotary screw trap operation}

The day-to-day operation of rotary screw traps can pose some difficulty. The traps are at the mercy of the watershed at all times while suspended in the stream. Alterations in flow regime and/or weather events can cause debris to pile up on or in the smolt trap. This can damage the trap and endanger crew members. To alleviate these potential hazards, traps were pulled when necessary. During this study period, a total of 32 days were lost to trapping. Peak flow events accounted for 22 days of trapping lost in May and June. Evening wind events in late October and November contributed to all 6 days of trapping lost during this period. These weather events inundated screw trap live boxes with autumn leaves to the point the rotary cone would stop and sink. Sporadic trap repairs and failures contributed to the remaining trapping days lost.

\section{Summer vs. spring Chinook}

Both spring and summer Chinook spawn in the Entiat basin. Early in the season, distinct morphological differences between summer sub-yearlings and spring Chinook yearlings make identification easy. Spring Chinook yearlings are much larger in size $(100-150 \mathrm{~mm})$ in comparison to newly emergent summer Chinook fry (32-45 mm). Juveniles produced from the Entiat exhibit life history characteristics that make identification easy in the spring. This identification is much more difficult in late summer and early fall as subyearlings representing both the spring and summer Chinook out-migration life histories most likely overlap each other. During this time it is likely that spring Chinook subyearlings can be found migrating within the basin as well. Currently a definitive method to apportion these two runs of sub-yearlings is problematic and unverified. In previous years this issue was addressed utilizing an estimation of population differences in outmigrant timing and fork length. In order to tease out the difference in migration timing, total catch was monitored and plotted by day. When catch dwindled and a relative nadir was reached in early September, all Chinook captured onward were identified based on any detectable break in fork length distributions. Undoubtedly, some Chinook were identified improperly using this method. This was further illustrated after the installation of PIT tag antenna array interrogation sites in the Entiat basin. Utilizing the data from these interrogation sites and the timing of emigration from Chinook PIT tagged in 2007, it became increasingly clear that delineation of the two runs of sub-yearling Chinook used in previous years was inadequate at best. To alleviate this potential improper 
identification, sub-yearling Chinook PIT tagged after the spring migration were identified as wild Chinook of unknown run.

\section{Project goals}

Project goals were met during the 2008 field season. In order to evaluate the success of wild steelhead and spring Chinook, continued out-migrant monitoring is required. This is especially relevant, as the ENFH has discontinued the propagation of spring Chinook salmon as of 2007.

\section{Methods- snorkel surveys}

Fish were surveyed by direct observation using single-pass snorkeling method as described in Murdoch and Nelle (2008) and by Thurow (1994).

\section{Snorkel site selection}

Snorkel site locations were identified jointly by USFWS and Terraqua, Inc. Site locations were defined by using locations of proposed habitat structures (treatment sites), locations of existing habitat structures (pre-existing treatment sites), and information from Rosgen stream typing classification methods to select sites with a similar channel types as treatment sites for sites not subject to modifications (control sites).

Treatment and pre-existing treatment sites were setup to place the area surveyed in the middle of the section to be modified or presently modified. Snorkel sites were defined to be $200 \mathrm{~m}$ in length in the main river sites and $240 \mathrm{~m}$ or less in off-channel sites. Each site was further divided into habitat units, monumented, and flagged.

\section{Snorkel surveys}

Snorkel surveys were conducted at three time periods throughout the year: winter period (February/March), summer period (July/August after peak discharge), and fall period (mid-October/November). The winter and fall survey periods were snorkeled at night, while the summer period was conducted during the daytime.

Night snorkeling commenced no earlier than 30 minutes past the official sunset at Entiat, WA, or after the first star or planet was observed in the sky. Prior to night snorkeling, glow sticks or reflectors were affixed at habitat unit breaks to assist crews in locating the sample site.

Up to nine snorkelers and at least one shore tender were used to conduct the snorkel surveys in the mainstem river snorkel sites. Off channel sites were snorkeled by one to four snorkelers depending on the site width. Snorkel crews entered the snorkel site downstream of the site and snorkeled as a unit in an upstream direction to the end of the site. Snorkelers were positioned across the stream channel so as to cover the entire channel bank to bank. Shore tenders estimated fish numbers in the water too shallow to snorkel. Snorkelers used dry suits, wet or dry gloves, felt bottom wading boots, a mask and a snorkel. Hand-held dive lights were used at night to illuminate the survey area. 
Data were recorded by each snorkeler on a PVC cuff secured to their arm and data were transferred to a datasheet at the end of each habitat unit. Fish count data from snorkelers were recorded on datasheets by fish size and snorkel lanes looking upstream left to right. All fish observed were counted by species and assigned to a $20 \mathrm{~mm}$ size class within each habitat unit. Water temperature was collected at the start and end of each site. Turbidity water samples were collected once during at each site and processed following the snorkel survey. As a measure of the visibility, the distance that three snorkelers could identify a $100 \mathrm{~mm}$ rainbow trout fish lure (Rapala Model \#XRD-10RT) suspended in the water as a fish was recorded.

In the office, data were transferred to a database and proofed for concurrence with field datasheets.

\section{Results-snorkel surveys}

Snorkel sites

During the winter 2008 snorkel period 24 previous sample sites were snorkeled (Table 7). An additional 6 new sites were added before the 2008 summer sample period providing 30 sites to be snorkeled for both the 2008 summer and fall snorkel periods (Table 8). In order to capture the effects of a proposed treatment action near the Knapp-Wham main control site, this site was split to create two new sites, one a control and one a treatment. A new 200 m control site was established downstream which included the downstream $100 \mathrm{~m}$ from the previously sampled Knapp-Wham main control site and named KnappWham lower (Table 8). The upstream $100 \mathrm{~m}$ from the Knapp-Wham main control site was then included in a new 200 m treatment site named Knapp-Wham upper (Table 8).

Discharge

Daily mean discharge for all sites and periods ranged from a low of $125 \mathrm{ft}^{3} / \mathrm{sec}$ during the fall snorkel to a high of $198 \mathrm{ft}^{3} / \mathrm{sec}$ the during winter snorkel (Table 9). Daily mean discharge within a sample period varied from $26 \mathrm{ft}^{3} / \mathrm{sec}$ during the winter period, $24 \mathrm{ft}^{3} / \mathrm{sec}$ during the summer period and $37 \mathrm{ft}^{3} / \mathrm{sec}$ during the fall period. Snorkel surveys were conducted during low water periods of the year, which is reflected in the seasonal hydrograph (

Figure 3). The winter snorkel surveys were conducted during a period of increasing discharge where as the summer snorkel surveys were conducted during a period of descending discharge. The fall snorkel survey was conducted during a period where the discharge increased in the middle of the period.

\section{Water temperature}

Water temperatures within a sample period varied from $4.0^{\circ} \mathrm{C}$ to $10.3^{\circ} \mathrm{C}$ during 2008 (Table 9). Mean water temperature for the three sample periods were: winter period 5.1 ${ }^{\circ} \mathrm{C}$ (SD 1.5), summer period $17.8{ }^{\circ} \mathrm{C}$ (SD 2.6), and fall period was $8.2{ }^{\circ} \mathrm{C}$ (SD 1.1). 
Turbidity

Mean water turbidity by period was 0.6 NTU (SD 0.2) during the winter, 0.7 NTU (SD 0.3 ) during the summer period and 0.8 NTU (0.3) during the fall period (Table 99).

Table 7. Experimental site descriptions and locations snorkeled in the Entiat River during the winter 2008 period.

\begin{tabular}{lcccccc}
\hline \multicolumn{1}{c}{ Site name } & $\begin{array}{c}\text { Experimental } \\
\text { site type }\end{array}$ & $\begin{array}{c}\text { Channel } \\
\text { location }\end{array}$ & $\begin{array}{c}\text { River } \\
\text { kilometer } \\
(\mathbf{k m})\end{array}$ & $\begin{array}{c}\text { Site } \\
\text { length } \\
(\mathbf{m})\end{array}$ & \multicolumn{2}{c}{$\begin{array}{c}\text { Mid-point } \\
\text { coordinates }\end{array}$} \\
& & & Lan & Long (W) \\
\hline City limits main & Treatment & Main & 0.5 & 200 & 47.66320 & 120.23643 \\
City limits side channel & Treatment & Off & 0.5 & 200 & 47.66320 & 120.23643 \\
Keystone Canyon & Treatment & Main & 3.7 & 200 & 47.66528 & 120.26584 \\
Milne & Treatment & Main & 4.3 & 200 & 47.66546 & 120.27232 \\
Whitehall cross vane & Treatment & Main & 5.5 & 200 & 47.66920 & 120.28440 \\
PUD canal & Treatment & Off & 5.5 & 240 & 47.66860 & 120.28298 \\
Harrison lower side & Treatment & Off & 6.0 & 200 & 47.67064 & 120.28817 \\
Harrison upper side & Treatment & Off & 6.4 & 200 & 47.66993 & 120.29232 \\
Harrison main & Treatment & Main & 6.4 & 200 & 47.66993 & 120.29232 \\
Dinkelman cross vane & Existing treatment & Main & 7.4 & 200 & 47.67207 & 120.30595 \\
Stanton-Love & Treatment & Main & 8.4 & 200 & 47.67761 & 120.31252 \\
Hanan-Detwiler ditch & Control & Off & 8.4 & 200 & 47.67616 & 120.31201 \\
Jon Small barbs & Existing treatment & Main & 8.8 & 200 & 47.68088 & 120.31263 \\
Knapp-Wham main & Control & Main & 9.3 & 200 & 47.68556 & 120.31562 \\
Knapp-Wham ditch & Control & Off & 9.3 & 100 & 47.68609 & 120.31564 \\
Moen & Treatment & Off & 10.0 & 200 & 47.69201 & 120.31679 \\
Wilson main & Existing treatment & Main & 10.6 & 200 & 47.69548 & 120.32093 \\
Wilson side channel & Existing treatment & Off & 10.6 & 200 & 47.69606 & 120.32128 \\
Hatchery & Control & Main & 10.9 & 200 & 47.69869 & 120.32396 \\
CDLT/ Moraine & Control & Main & 26.5 & 200 & 47.80231 & 120.40202 \\
Deskin / Wortz & Existing treatment & Main & 28.0 & 200 & 47.81224 & 120.41138 \\
Stormy Preserve lower & Treatment & Main & 29.4 & 200 & 47.22001 & 120.42350 \\
Stormy Preserve mid & Treatment & Main & 29.8 & 200 & 47.82387 & 120.42124 \\
Sego/Yurt & Treatment & Main & 34.4 & 200 & 47.86131 & 120.42066 \\
\hline
\end{tabular}


Table 8. Experimental site descriptions and locations snorkeled in the Entiat River during the summer and fall 2008 periods.

\begin{tabular}{|c|c|c|c|c|c|c|}
\hline \multirow[t]{2}{*}{ Site name } & \multirow[t]{2}{*}{$\begin{array}{l}\text { Experimental } \\
\text { site type }\end{array}$} & \multirow[t]{2}{*}{$\begin{array}{l}\text { Channel } \\
\text { location }\end{array}$} & \multirow{2}{*}{$\begin{array}{c}\text { River } \\
\text { kilometer } \\
(\mathbf{k m}) \\
\end{array}$} & \multirow{2}{*}{$\begin{array}{c}\text { Site } \\
\text { length } \\
(\mathrm{m}) \\
\end{array}$} & \multicolumn{2}{|c|}{$\begin{array}{c}\text { Mid-point } \\
\text { coordinates }\end{array}$} \\
\hline & & & & & Lat $(\mathrm{N})$ & Long (W) \\
\hline City limits main & Control & Main & 0.5 & 200 & 47.66320 & 120.23643 \\
\hline City limits side & Control & Off & 0.5 & 200 & 47.66320 & 120.23643 \\
\hline Split Channel North ${ }^{\text {a }}$ & Treatment & Main & 2.3 & 200 & 47.66293 & 120.24875 \\
\hline Split Channel South ${ }^{\text {a }}$ & Treatment & Main & 2.3 & 200 & 47.66274 & 120.24916 \\
\hline Foreman statues $^{\text {a }}$ & Control & Main & 3.4 & 200 & 47.66477 & 120.26286 \\
\hline Keystone Canyon & Treatment & Main & 3.7 & 200 & 47.66528 & 120.26584 \\
\hline Milne & Treatment & Main & 4.3 & 200 & 47.66546 & 120.27232 \\
\hline Whitehall cross vane & Treatment & Main & 5.5 & 200 & 47.66920 & 120.28440 \\
\hline PUD side & Treatment & Off & 5.5 & 240 & 47.66860 & 120.28298 \\
\hline Harrison lower side & Treatment & Off & 6.0 & 200 & 47.67064 & 120.28817 \\
\hline Harrison pond & Treatment & Off & 6.4 & 200 & 47.66993 & 120.29232 \\
\hline Harrison main ${ }^{a}$ & Treatment & Main & 6.4 & 200 & 47.66993 & 120.29232 \\
\hline Harrison upper & Control & Main & 6.6 & 200 & 47.66944 & 120.29823 \\
\hline Dinkelman cross vane & Existing treatment & Main & 7.4 & 200 & 47.67207 & 120.30595 \\
\hline Stanton-Love & Treatment & Main & 8.4 & 200 & 47.67761 & 120.31252 \\
\hline Hanan-Detwiler ditch & Control & Off & 8.4 & 200 & 47.67616 & 120.31201 \\
\hline Jon Small barbs & Existing treatment & Main & 8.8 & 200 & 47.68088 & 120.31263 \\
\hline Knapp-Wham upper a, b & Treatment & Main & 9.4 & 200 & 47.68507 & 120.31535 \\
\hline Knapp-Wham lower ${ }^{\text {a c }}$ & Control & Main & 9.2 & 200 & 47.68453 & 120.31426 \\
\hline Knapp-Wham ditch & Control & Off & 9.3 & 100 & 47.68609 & 120.31564 \\
\hline Moen & Treatment & Off & 10.0 & 200 & 47.69201 & 120.31679 \\
\hline Wilson main & Control & Main & 10.6 & 200 & 47.69548 & 120.32093 \\
\hline Wilson side channel & Existing treatment & Off & 10.6 & 200 & 47.69606 & 120.32128 \\
\hline Hatchery & Control & Main & 10.9 & 200 & 47.69869 & 120.32396 \\
\hline Powerline $^{\mathrm{a}}$ & Control & Main & 13.2 & 200 & 47.71498 & 120.33564 \\
\hline CDLT Moraine & Control & Main & 26.5 & 200 & 47.80231 & 120.40202 \\
\hline Deskin-Wortz & Existing treatment & Main & 28.0 & 200 & 47.81224 & 120.41138 \\
\hline Lower Stormy & Control & Main & 29.4 & 200 & 47.22001 & 120.42350 \\
\hline Upper Stormy & Treatment & Main & 29.8 & 200 & 47.82387 & 120.42124 \\
\hline Sego/Yurt & Treatment & Main & 34.4 & 200 & 47.86131 & 120.42066 \\
\hline
\end{tabular}


Table 9. Water quality measurements for sites and times snorkeled in the Entiat River during 2008. Mean discharge data is from USGS gage site number 12452990.

\begin{tabular}{|c|c|c|c|c|c|c|}
\hline $\begin{array}{c}\text { Survey period- } \\
\text { snorkel time }\end{array}$ & Site name & $\begin{array}{c}\begin{array}{c}\text { River } \\
\text { kilometer } \\
(\mathbf{k m})\end{array} \\
\end{array}$ & $\begin{array}{c}\text { Snorkel } \\
\text { date } \\
\end{array}$ & $\begin{array}{c}\text { Discharge } \\
\left(\mathrm{ft}^{3} / \mathrm{sec}\right) \\
\end{array}$ & $\begin{array}{c}\text { Temperature } \\
\square \mathrm{C} \\
\end{array}$ & $\begin{array}{c}\text { Turbidity } \\
\text { NTU } \\
\end{array}$ \\
\hline \multirow[t]{24}{*}{ Winter- Night } & City Limits Main & 0.5 & $03 / 11 / 08$ & 195 & 5.8 & 0.87 \\
\hline & City Limits Side & 0.5 & 03/11/08 & 195 & 5.8 & 0.87 \\
\hline & Keystone Canyon & 3.7 & 03/06/08 & 172 & 5.3 & 0.54 \\
\hline & Milne & 4.3 & 03/06/08 & 172 & 4.7 & 0.67 \\
\hline & PUD Side & 5.5 & 03/04/08 & 178 & 4.4 & 0.57 \\
\hline & Whitehall Cross Vane & 5.5 & 03/04/08 & 178 & 4.6 & 0.57 \\
\hline & Harrison Lower Side & 6.0 & 03/12/08 & 198 & 10.0 & 0.33 \\
\hline & Harrison Pond & 6.1 & 03/12/08 & 198 & 8.5 & NA \\
\hline & Harrison Main & 6.4 & 03/06/08 & 172 & 5.0 & 0.67 \\
\hline & Dinkleman Cross Vane & 7.4 & 03/04/08 & 178 & 5.1 & 0.59 \\
\hline & Hanan-Detwiler Ditch & 8.4 & 03/12/08 & 198 & 6.5 & 0.72 \\
\hline & Stanton-Love & 8.4 & 03/05/08 & 176 & 4.5 & 0.67 \\
\hline & Jon Small Barbs & 8.8 & 03/05/08 & 176 & 3.5 & 0.59 \\
\hline & Knapp-Wham Main & 9.3 & 03/03/08 & 176 & 4.7 & 0.85 \\
\hline & Knapp-Wham Ditch & 9.3 & 03/03/08 & 176 & 4.6 & 0.85 \\
\hline & Moen & 10.0 & 03/12/08 & 198 & 6.0 & 0.59 \\
\hline & Wilson Main & 10.6 & 03/03/08 & 176 & 3.9 & 0.72 \\
\hline & Wilson Side & 10.6 & 03/12/08 & 198 & 5.3 & 0.56 \\
\hline & Hatchery & 10.9 & 03/11/08 & 195 & 5.0 & 0.72 \\
\hline & CDLT Morraine & 26.5 & 03/10/08 & 190 & 4.3 & 0.31 \\
\hline & Deskin/Wortz & 28.0 & 03/10/08 & 190 & 4.8 & 0.26 \\
\hline & Lower Stormy & 29.4 & 03/10/08 & 190 & 4.0 & 0.42 \\
\hline & Upper Stormy & 29.8 & 03/10/08 & 190 & 4.0 & 0.42 \\
\hline & Sego-Yurt & 34.4 & 03/10/08 & 190 & 3.5 & 0.53 \\
\hline \multirow[t]{18}{*}{ Summer- Day } & City Limits Main & 0.5 & 08/13/08 & 172 & 20.0 & 0.67 \\
\hline & City Limits Side & 0.5 & 08/14/08 & 169 & 21.5 & 0.76 \\
\hline & Split Channel North & 2.3 & 08/19/08 & 172 & 20.3 & 0.84 \\
\hline & Split Channel South & 2.3 & 08/20/08 & 175 & 17.5 & 0.61 \\
\hline & Foreman Statues & 3.5 & 08/15/08 & 169 & 17.8 & 0.47 \\
\hline & Keystone Canyon & 3.7 & 08/14/08 & 169 & 21.5 & 0.76 \\
\hline & Milne & 4.3 & 08/11/08 & 193 & 17.8 & 0.81 \\
\hline & PUD Side & 5.5 & 08/14/08 & 169 & 19.0 & 0.62 \\
\hline & Whitehall Cross Vane & 5.5 & $08 / 14 / 08$ & 169 & 19.0 & 0.62 \\
\hline & Harrison Lower Side & 6.0 & 08/20/08 & 175 & 20.9 & 1.75 \\
\hline & Harrison Pond & 6.1 & 08/20/08 & 175 & NA & NA \\
\hline & Harrison Main & 6.4 & 08/15/08 & 169 & 18.5 & 0.51 \\
\hline & Harrison Upper & 6.4 & 08/19/08 & 172 & 19.5 & 0.69 \\
\hline & Dinkleman Cross Vane & 7.4 & $08 / 14 / 08$ & 169 & 16.0 & 0.55 \\
\hline & Hanan-Detwiler Ditch & 8.4 & 08/20/08 & 175 & 17.0 & 0.48 \\
\hline & Stanton-Love & 8.4 & 08/13/08 & 172 & 16.3 & 0.61 \\
\hline & Jon Small Barbs & 8.8 & 08/11/08 & 193 & 17.0 & 0.87 \\
\hline & Knapp-Wham lower & 9.3 & $08 / 18 / 08$ & 172 & 19.0 & 0.71 \\
\hline
\end{tabular}


Table 9. Water quality measurements for sites and times snorkeled in the Entiat River from 2008. Mean discharge data is from USGS gage site number 12452990, continued.

\begin{tabular}{|c|c|c|c|c|c|c|}
\hline $\begin{array}{c}\text { Survey period- } \\
\text { snorkel time }\end{array}$ & Site name & $\begin{array}{c}\begin{array}{c}\text { River } \\
\text { kilometer } \\
(\mathbf{k m})\end{array} \\
\end{array}$ & $\begin{array}{c}\text { Snorkel } \\
\text { date } \\
\end{array}$ & $\begin{array}{c}\text { Discharge } \\
\left(\mathbf{f t}^{3} / \mathbf{s e c}\right)\end{array}$ & $\begin{array}{c}\text { Temperature } \\
\square \mathbf{C} \\
\end{array}$ & $\begin{array}{c}\text { Turbidity } \\
\text { NTU } \\
\end{array}$ \\
\hline \multirow[t]{12}{*}{ Summer- Day } & Knapp-Wham upper & 9.5 & 08/18/08 & 172 & 19.8 & 0.77 \\
\hline & Knapp-Wham Ditch & 9.3 & 08/20/08 & 175 & 17.0 & 0.53 \\
\hline & Moen & 10.0 & 08/20/08 & 175 & 18.0 & 0.78 \\
\hline & Wilson Main & 10.6 & 08/19/08 & 172 & 17.5 & 0.62 \\
\hline & Wilson Side & 10.6 & 08/13/08 & 172 & 19.8 & 1.16 \\
\hline & Hatchery & 10.9 & 08/18/08 & 172 & 20.8 & 0.76 \\
\hline & Powerline & 13.2 & 08/19/08 & 172 & 17.3 & 0.61 \\
\hline & CDLT Morraine & 26.5 & 08/12/08 & 180 & 15.0 & 0.36 \\
\hline & Deskin/Wortz & 28.0 & 08/12/08 & 180 & 14.8 & 0.43 \\
\hline & Lower Stormy & 29.4 & 08/12/08 & 180 & 13.0 & 0.39 \\
\hline & Upper Stormy & 29.8 & 08/12/08 & 180 & 13.3 & 0.57 \\
\hline & Sego-Yurt & 34.4 & 08/12/08 & 180 & 11.3 & 0.34 \\
\hline \multirow[t]{30}{*}{ Fall- Night } & City Limits Main & 0.5 & $10 / 16 / 08$ & 125 & 10.5 & 0.78 \\
\hline & City Limits Side & 0.5 & 10/21/08 & 132 & 9.3 & 0.70 \\
\hline & Split Channel North & 2.3 & $10 / 16 / 08$ & 125 & 10.3 & 0.72 \\
\hline & Split Channel South & 2.3 & $10 / 16 / 08$ & 125 & 10.0 & 0.72 \\
\hline & Foreman Statues & 3.5 & $10 / 07 / 08$ & 139 & 9.5 & 1.69 \\
\hline & Keystone Canyon & 3.7 & $10 / 07 / 08$ & 139 & 9.0 & 1.69 \\
\hline & Milne & 4.3 & $10 / 08 / 08$ & 162 & 8.0 & 0.78 \\
\hline & PUD Side & 5.5 & $10 / 14 / 08$ & 125 & 8.3 & 0.82 \\
\hline & Whitehall Cross Vane & 5.5 & $10 / 14 / 08$ & 125 & 8.3 & 0.67 \\
\hline & Harrison Lower Side & 6.0 & $10 / 15 / 08$ & 130 & 7.0 & 0.62 \\
\hline & Harrison Pond & 6.1 & $10 / 21 / 08$ & 132 & 9.5 & 0.75 \\
\hline & Harrison Main & 6.4 & $10 / 08 / 08$ & 162 & 8.3 & 0.79 \\
\hline & Harrison Upper & 6.4 & $10 / 08 / 08$ & 162 & 8.0 & 0.79 \\
\hline & Dinkleman Cross Vane & 7.4 & $10 / 14 / 08$ & 125 & 7.3 & 0.81 \\
\hline & Hanan-Detwiler Ditch & 8.4 & $10 / 15 / 08$ & 130 & 6.5 & 0.70 \\
\hline & Stanton-Love & 8.4 & 10/15/08 & 130 & 8.0 & 0.70 \\
\hline & Jon Small Barbs & 8.8 & $10 / 15 / 08$ & 130 & 8.0 & 0.57 \\
\hline & Knapp-Wham lower & 9.3 & $10 / 09 / 08$ & 137 & 7.0 & 0.66 \\
\hline & Knapp-Wham upper & 9.5 & $10 / 09 / 08$ & 137 & 7.0 & 0.66 \\
\hline & Knapp-Wham Ditch & 9.3 & $10 / 09 / 08$ & 137 & 7.0 & 0.66 \\
\hline & Moen & 10.0 & $10 / 15 / 08$ & 130 & 6.5 & 0.74 \\
\hline & Wilson Main & 10.6 & $10 / 14 / 08$ & 125 & 7.5 & 0.52 \\
\hline & Wilson Side & 10.6 & $10 / 21 / 08$ & 132 & 8.5 & 1.66 \\
\hline & Hatchery & 10.9 & 10/09/08 & 137 & 7.0 & 0.61 \\
\hline & Powerline & 13.2 & $10 / 16 / 08$ & 125 & 8.0 & 0.49 \\
\hline & CDLT Morraine & 26.5 & $10 / 06 / 08$ & 139 & 9.0 & 1.28 \\
\hline & Deskin/Wortz & 28.0 & 10/16/08 & 125 & 8.5 & 0.41 \\
\hline & Lower Stormy & 29.4 & $10 / 06 / 08$ & 139 & 8.3 & 1.21 \\
\hline & Upper Stormy & 29.8 & $10 / 06 / 08$ & 139 & 8.3 & 1.21 \\
\hline & Sego-Yurt & 34.4 & $10 / 07 / 08$ & 139 & 7.8 & 0.54 \\
\hline
\end{tabular}




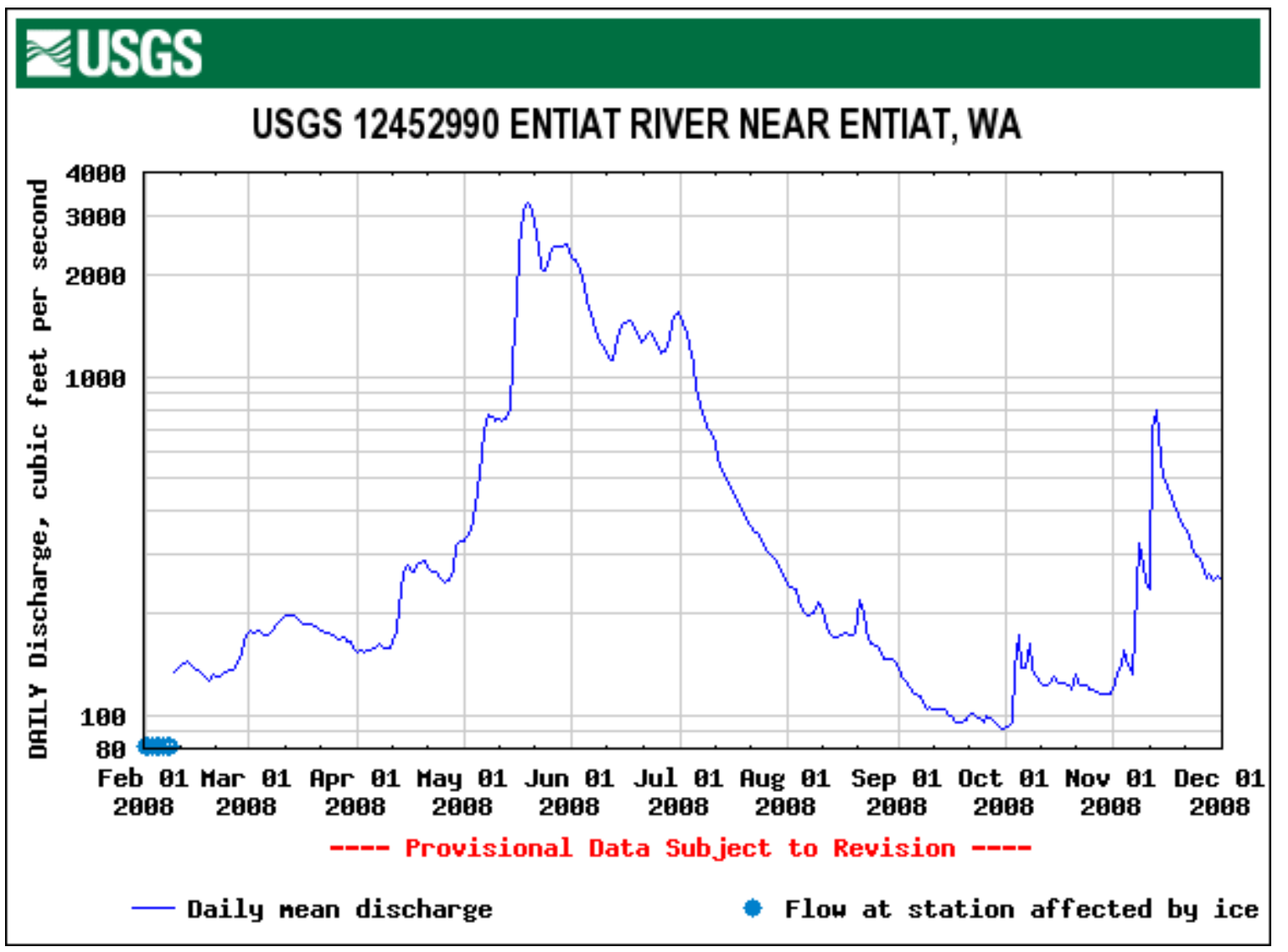

Figure 3. Daily mean discharge $\left(\mathrm{ft}^{3} / \mathrm{sec}\right)$ for the period from February 1 to December 1 , 2008 for USGS gage station 12452990 at rkm 2.3 in the Entiat River.

\section{Discussion-snorkel surveys}

Snorkel surveys conducted by the MCRFRO in the Entiat River during 2008 as part of the Integrated Status and Effectiveness Monitoring Program in the Entiat River were conducted on time and within the planned sample periods. These snorkel surveys were conducted under low flows and low turbidity conditions creating ideal snorkeling conditions.

Starting with the summer 2008 survey period, six new treatment sites were added to the snorkeling schedule. This included a modification of the original $200 \mathrm{~m}$ Knapp-Wham control site in which this site was split with the upper $100 \mathrm{~m}$ going to the new $200 \mathrm{~m}$ Knapp-Wham upper site (treatment) and the lower 100 m going into the Knapp-Wham lower site (control).

During 2008, one modification occurred using restoration methods which influence three snorkel sites. The Harrison Main site at $6.4 \mathrm{rkm}$ was treated by opening a channel on river left that connects to a temporary pond at the Harrison pond site. Water then flows 
through a series of channels and beaver dams to a high water channel at Harrison lower side. All construction occurred between the summer and fall 2008 snorkel surveys.

Project goals were met during the 2008 field season. Continued snorkel surveys will be needed to evaluate the before and after restoration efforts and meet the long-term effectiveness monitoring program goals in the Entiat River.

\section{Methods- steelhead redd surveys}

Steelhead redd surveys were conducted as described in Nelle and Moberg (2008). Steelhead redd survey reach lengths were chosen by the presence of access points and sections of the Entiat River that could be rafted in one day. Four reaches were surveyed in the Entiat River during 2008. Reach A is from rkm 1.1 near the information kiosk to the Entiat National Fish Hatchery abatement pond outfall at rkm 10.6. Reach B is from rkm 10.6 to the start of the stillwater section below the McKenzie diversion dam at rkm 25.9. Section C is from rkm 25.9 to the private bridge near Brief at rkm 37.7. Reach D is from rkm 37.7 to top of the spawning channel at rkm 44.2. Entiat River steelhead redd surveys were primarily conducted in a downstream manner using two single man $10 \mathrm{ft}$ catarafts. Foot surveys were used to access areas that were not accessible with a raft. Upon locating a disturbance in the substrate, the crew first determined if it was a redd. If the disturbance was judged to be a redd, measurements of maximum length, width, pit depth, and head depth were recorded. A GPS point was recorded, maps were drawn by hand showing stream features in relation to redds, and a point was placed on an air photo. A flag was place in a nearby on the bank. Each new redd was numbered consecutively within a reach. Redd surveys were conducted weekly as conditions allow.

\section{Results-steelhead redd surveys}

A total of 222 steelhead redds were identified during the 2008 spring redd surveys (Table 10). Reaches A and B (rkm 1.1 to 25.9) accounted for $80 \%$ of the steelhead redds identified in main Entiat River during 2008.

Redd surveys were initated on February 28, 2008 starting with Reach A and continued weekly until May 15, 2008 (Table 11). A final survey was completed in mid-June when no new redds were identified.

The first redd was located in Reach A during the first survey week on February 28, 2008 (Table 11). The number of redds counted per week for all reaches combined increased gradually through March 2008. During mid-April, the number of new redds observed increased markedly and by the end of April the number new redds identified had peaked (Table 11 and Figure 4). Due to high stream discharge and poor visibility the surveys were not conducted during a three week period from late May to early June 2008. 
Table 10. The number of steelhead redds by reach in the Entiat River from rkm 1.1 to 44.2. during the spring of 2008.

\begin{tabular}{cccccc}
\hline $\begin{array}{c}\text { Survey } \\
\text { reach }\end{array}$ & $\begin{array}{c}\text { Site location } \\
\text { river kilometer }\end{array}$ & Start date & End date & $\begin{array}{c}\text { Number } \\
\text { of } \\
\text { surveys }\end{array}$ & $\begin{array}{c}\text { Number } \\
\text { of } \\
\text { redds }\end{array}$ \\
\hline A & $1.1-10.6$ & February 28 & June 11 & 26 & 93 \\
B & $10.6-25.9$ & March 13 & June 16 & 11 & 84 \\
C & $25.9-37.7$ & March 17 & June 10 & 20 & 31 \\
D & $37.7-44.2$ & March 20 & June 9 & 16 & 14 \\
Total & & & & 73 & 222 \\
\hline
\end{tabular}

Table 11. The number of steelhead redds indentified in the Entiat River from rkm 1.1 to 44.2 during 2008.

\begin{tabular}{ccccccccccc}
\hline $\begin{array}{c}\text { Mid- } \\
\text { Week }\end{array}$ & \multicolumn{2}{c}{ Reach A } & \multicolumn{2}{c}{ Reach B } & \multicolumn{2}{c}{ Reach C } & \multicolumn{2}{c}{ Reach D } & \multicolumn{2}{c}{ All Reaches } \\
Date & New & Total & New & Total & New & Total & New & Total & New & Total \\
\hline $02 / 27 / 08$ & 1 & 1 & & & & & & & 1 & 1 \\
$03 / 05 / 08$ & 2 & 3 & & & & & & & 2 & 3 \\
$03 / 12 / 08$ & 4 & 7 & 2 & 2 & & & & & 6 & 9 \\
$03 / 19 / 08$ & 3 & 10 & 6 & 8 & 1 & 1 & & & 10 & 19 \\
$03 / 26 / 08$ & 1 & 11 & 0 & 0 & 1 & 2 & 0 & 0 & 2 & 21 \\
$04 / 02 / 08$ & 11 & 22 & 0 & 0 & 1 & 3 & 0 & 0 & 12 & 33 \\
$04 / 09 / 08$ & 17 & 39 & 0 & 0 & 3 & 6 & 3 & 3 & 23 & 56 \\
$04 / 16 / 08$ & 9 & 48 & 20 & 28 & 6 & 12 & 3 & 6 & 38 & 94 \\
$04 / 23 / 08$ & 20 & 68 & 26 & 54 & 9 & 21 & 3 & 9 & 58 & 152 \\
$04 / 30 / 08$ & 23 & 91 & 26 & 80 & 9 & 30 & 3 & 12 & 61 & 213 \\
$05 / 07 / 08$ & 2 & 93 & 4 & 84 & 0 & 30 & 1 & 13 & 7 & 220 \\
$05 / 14 / 08$ & 0 & 93 & 0 & 84 & 1 & 31 & 1 & 14 & 2 & 222 \\
$06 / 11 / 08$ & 0 & 93 & 0 & 84 & 0 & 31 & 0 & 14 & 0 & 222 \\
\hline
\end{tabular}

Steelhead redds were distributed throughout the entire survey area in locations where suitable substrate was located (Figures 5,6,7,8,9). Redds were also located in areas of disturbed substrate associated with habitat restoration sites and at the inlets of irrigation diversions. 


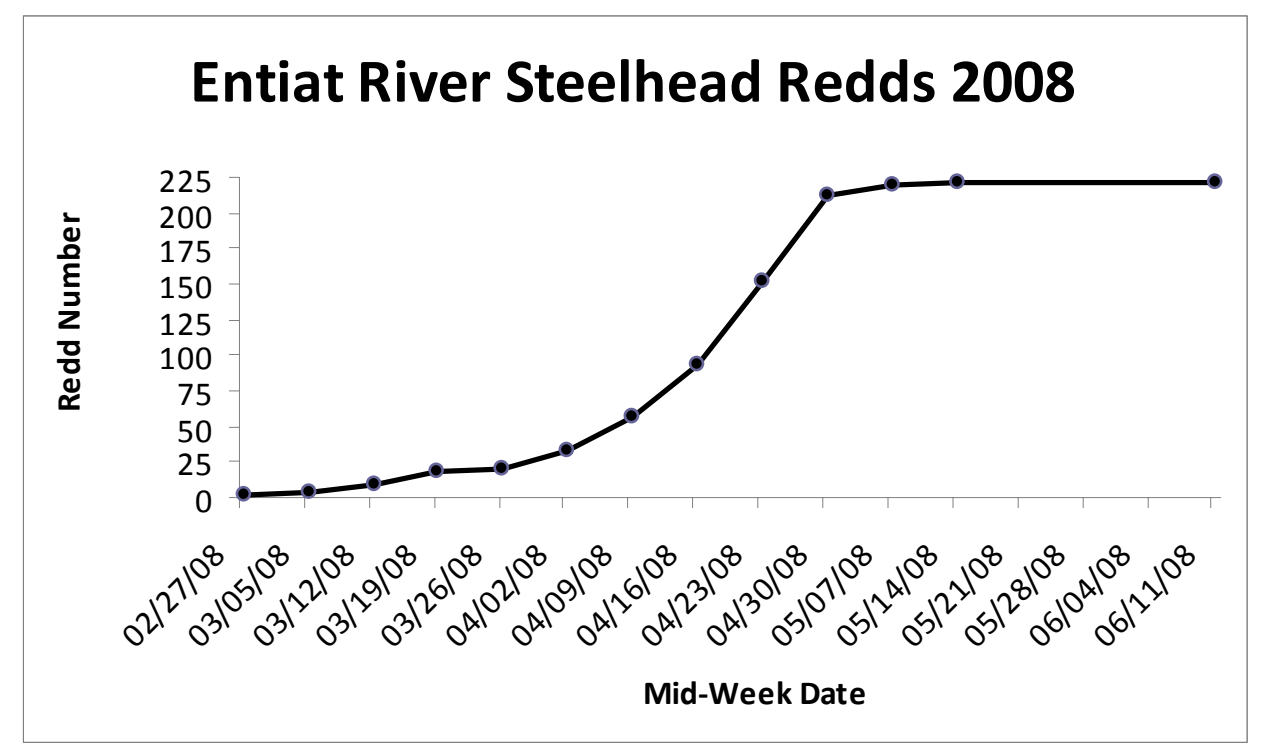

Figure 4. The cumulative number of number of steelhead redds indentified in the Entiat River from rkm 1.1 to 44.2 during 2008.

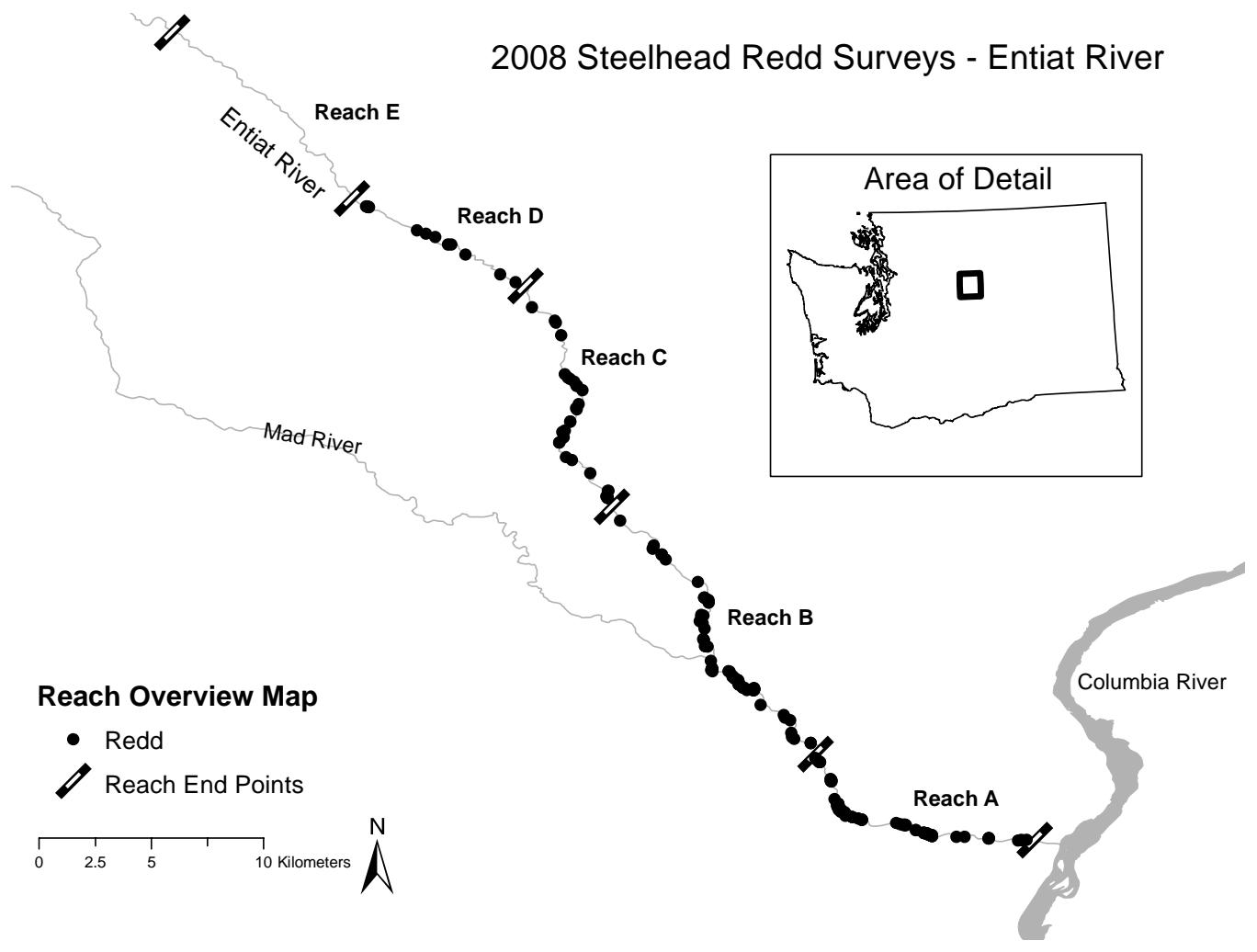

Figure 5. Distribution of steelhead redds in the main Entiat River in (rkm 1.1 to 44.2) during 2008. 


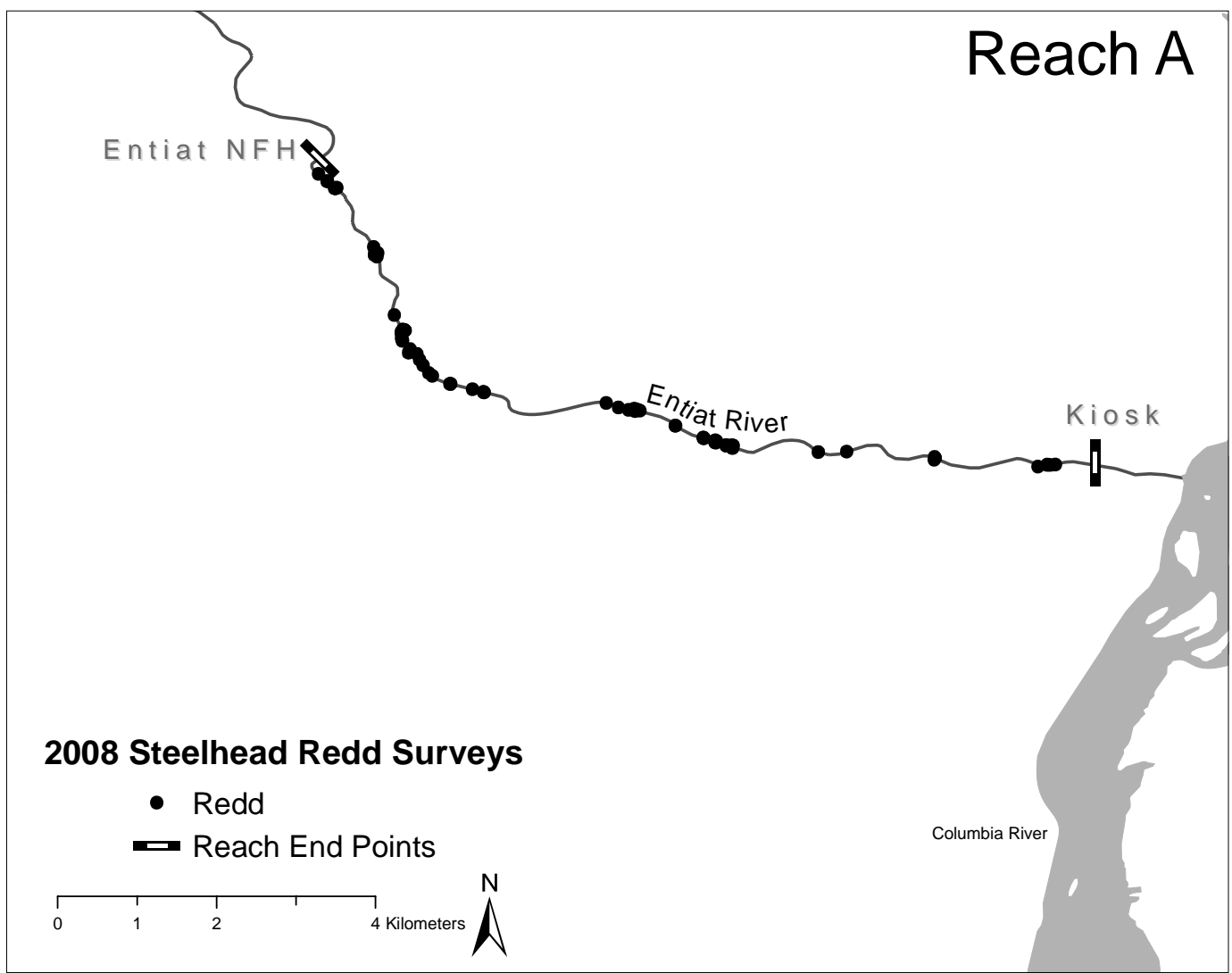

Figure 6. Distribution of steelhead redds in the Entiat River in Reach A (rkm 1.1 to 10.6) during 2008. 


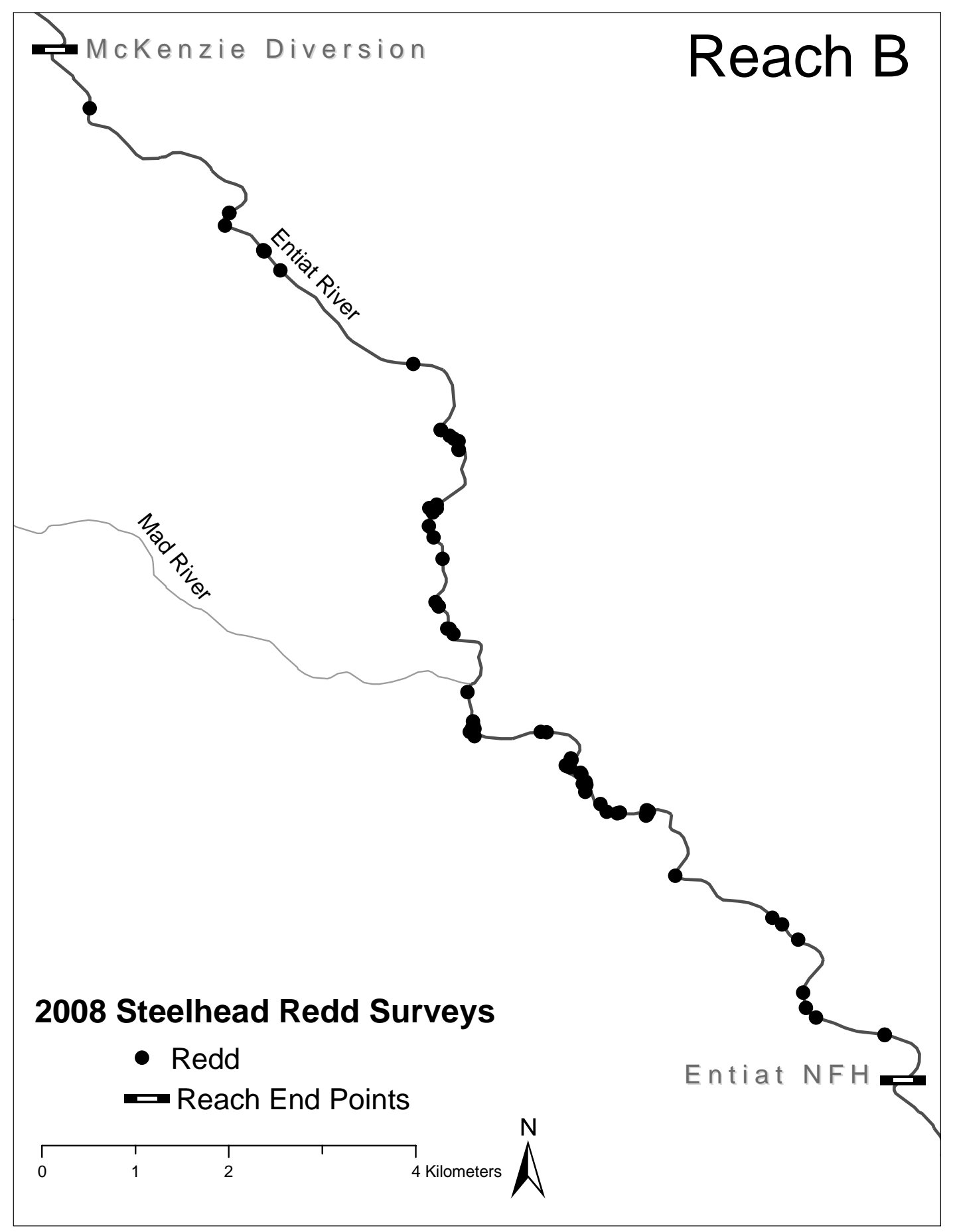

Figure 7. Distribution of steelhead redds in the Entiat River in Reach B (rkm 10.6 to 25.9) during 2008. 


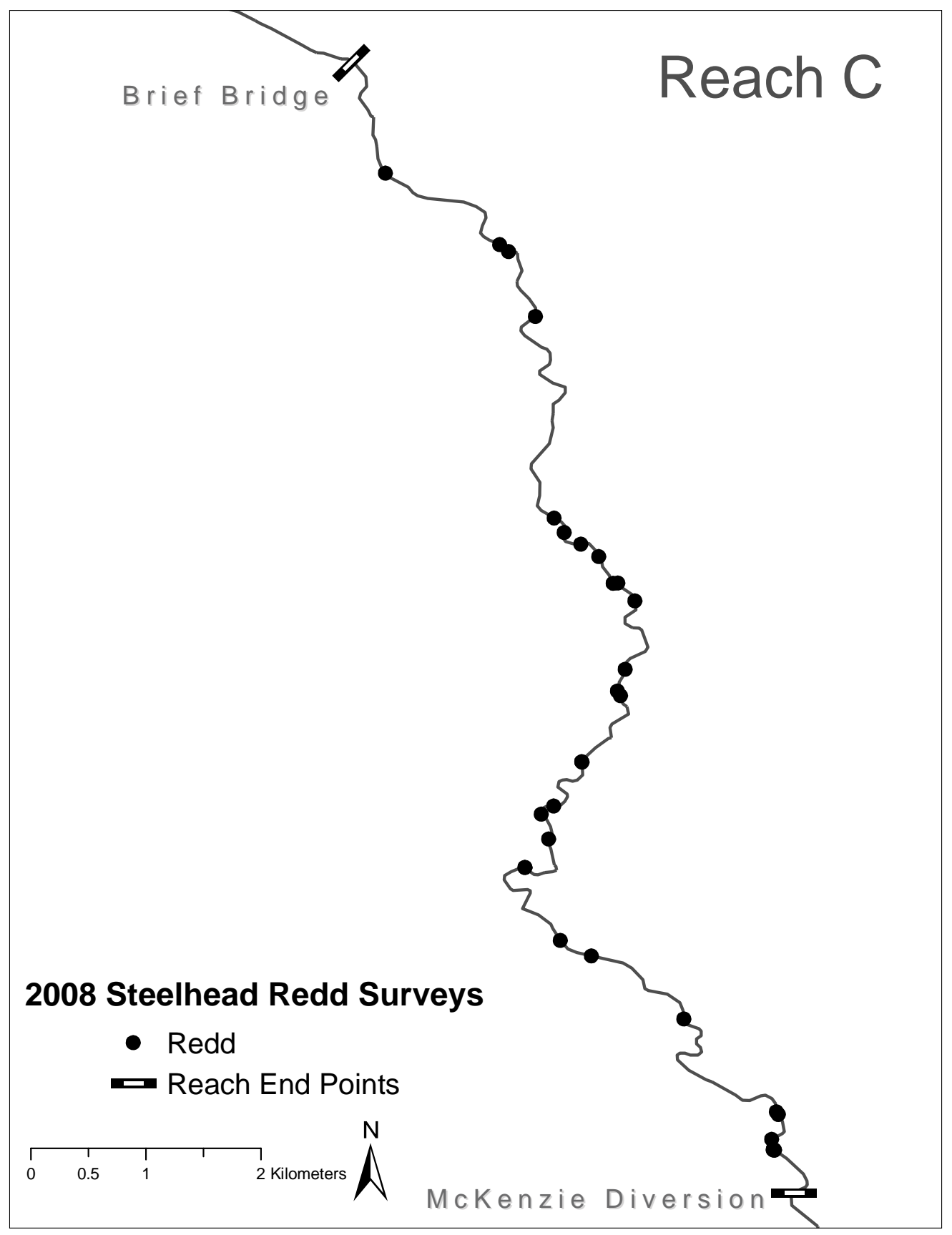

Figure 8. Distribution of steelhead redds in the Entiat River in Reach C (rkm 25.9 to 37.7) during 2008. 


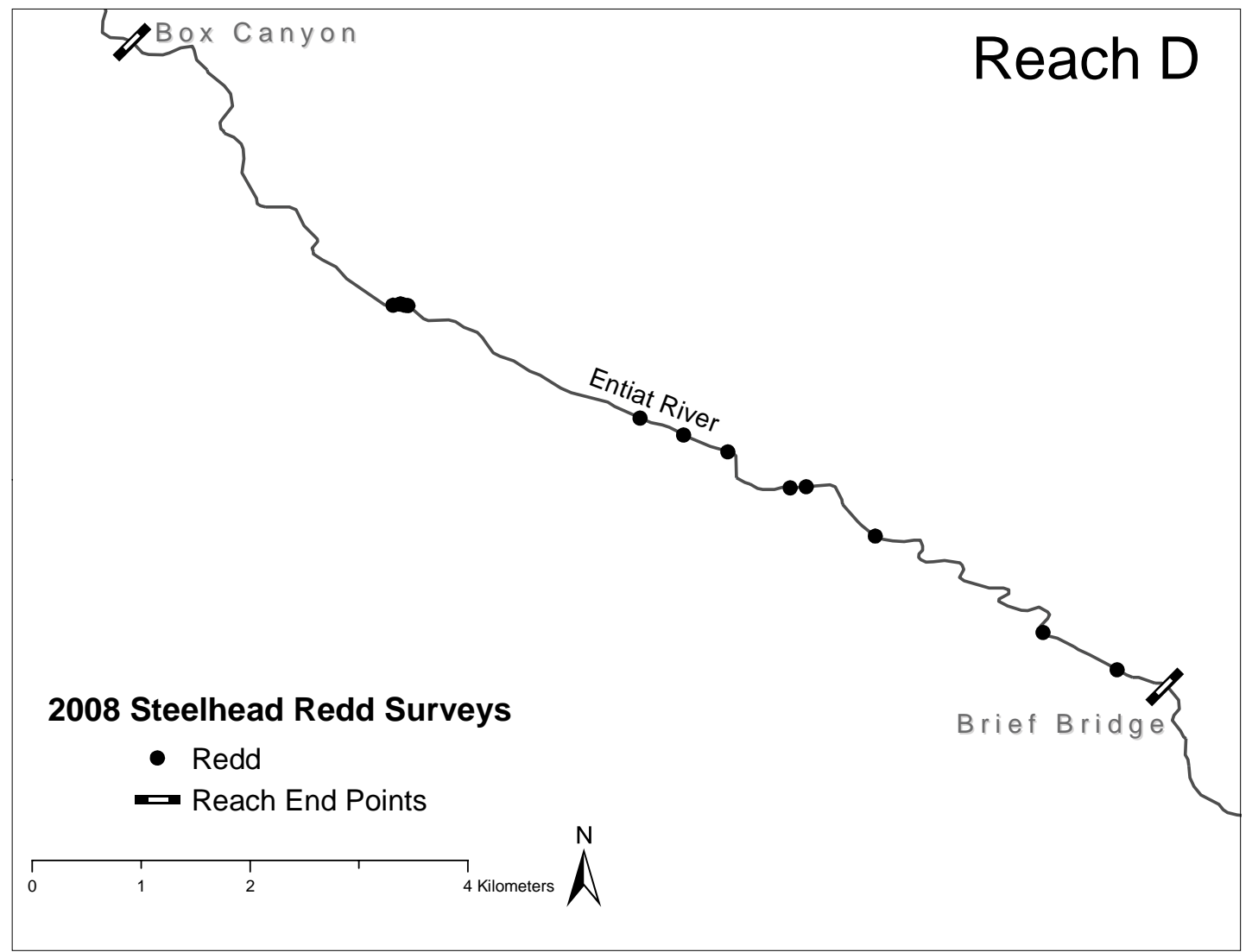

Figure 9. Distribution of steelhead redds in the Entiat River in Reach D (rkm 37.7 to 44.2) during 2008.

\section{Discussion-steelhead redd surveys}

The steelhead spawning period in the main Entiat River for 2008 occurred late February through May with April being the peak month of spawning. Steelhead redds were located in all survey reaches from near the mouth to rkm 44.2 with greatest numbers of redds located in the section of river downstream of rkm 26.

A zero count at the start of the survey season was obtained in Reach D. Surveys were delayed in Reach A, B and C due to ice conditions thus steelhead spawning had been initiated although low numbers of redds were detected during the first surveys.

Future surveys in Reaches A, B, and C in the Entiat River should be initiated in midFebruary if conditions allow, so zero counts can be achieved on the first survey. 


\section{Acknowledgements}

Many thanks go to the snorkelers from Mid-Columbia River Fisheries Resource Office, Leavenworth National Fish Hatchery, Yakama Nation, U.S. Forest Service, and Terraqua, Inc. Additional thanks goes to the snorkeling support and shelter provided by Entiat National Fish Hatchery.

Many thanks to the smolt trap crew: Erica Saginus, Jessica Coyle, Heather Trainer, and Charles O. Hamstreet. Thank you to the WDFW remote tagging crew for the collaborative assistance in providing the snerding, the effective angling, and the sharing of invaluable information. Also, a big thank you to the short notice support provided by Trout Unlimited, Wenatchee Valley Fly-Fishing Club, and the additional MCFRO staff of Robes Parrish, Andy Johnsen, Drew Pearson, Ben Truscott, Dave Carie, and Terry Dellapenna. And last but not least, this project would cease to exist without the support from Jason Reeves, Craig Eaton, and John Reir, the exceptional staff of Entiat National Fish Hatchery. 


\section{References}

Chelan County Conservation District. 2004. Entiat Water Resource Inventory (WRIA) 46 Management Plan. October 2004. Prepared for the Entiat Watershed Planning Unit by the Chelan County Conservation District. Wenatchee, Washington.

Mullan J. W., K. R. Williams, G. Rhodus, T. W. Hillman, J. McIntyre. 1992. Production and habitat of salmonids in the mid-Columbia River tributary streams. U.S. Fish and Wildlife Service Monograph I.

Murdoch and Nelle. 2008. A Field Manual of Scientific Protocols for Underwater Observations within the Upper Columbia Monitoring Strategy. Terraqua, Inc.

Nelle and Morberg 2008. A Field Manual of Scientific Protocols for Steelhead Redd Surveys within the Upper Columbia Monitoring Strategy. Terraqua, Inc

Terraqua, Inc. 2008. Interim Protocols for the Capture, Handling, and Tagging of Wild Salmonids in the Upper Columbia Basin using Passive Integrated Transponder (PIT) Tags. Terraqua, Inc.

Thurow, R.F. 1994. Underwater methods for study of salmonids in the Intermountain West. Gen. Tech. Report INT-GTR-307. USDA, Forest Service, Intermountain Research Station. Ogden, UT.

Tussing, S. P. 2008. A Field Manual of Downstream Migration Trapping Within the Upper Columbia Monitoring Strategy. Terraqua, Inc.

Wydoski R. S. and R. R. Whitney. 2003. Inland Fishes of Washington. American Fisheries Society University of Washington Press. 